\title{
Pathology of fatal lineage 1 and 2 West Nile virus infections in horses in South Africa
}

\begin{tabular}{|c|c|}
\hline $\begin{array}{l}\text { Authors: } \\
\text { June H. Willia } \\
\text { Stephanie var } \\
\text { Stacey Humar } \\
\text { Erna van Wilp } \\
\text { Marietjie Ven }\end{array}$ & $\begin{array}{l}\mathrm{ns}^{1,2} \\
\mathrm{Niekerk}^{2} \\
2 \\
\mathrm{e}^{3} \\
\mathrm{er}^{2,4}\end{array}$ \\
\hline $\begin{array}{l}\text { Affiliations: } \\
{ }^{1} \text { Department } \\
\text { Sciences, Uni } \\
\text { Pretoria, Sout }\end{array}$ & $\begin{array}{l}\text { f Paraclinical } \\
\text { ersity of } \\
\text { Africa }\end{array}$ \\
\hline $\begin{array}{l}{ }^{2} \text { Department } \\
\text { Virology, Univ } \\
\text { Pretoria, Sout }\end{array}$ & $\begin{array}{l}\text { f Medical } \\
\text { ersity of } \\
\text { Africa }\end{array}$ \\
\hline $\begin{array}{l}{ }^{3} \text { Department } \\
\text { University of } \\
\text { South Africa }\end{array}$ & $\begin{array}{l}\text { f Anatomy, } \\
\text { retoria, }\end{array}$ \\
\hline $\begin{array}{l}{ }^{4} \text { Centre for Re } \\
\text { Diseases and } \\
\text { National Instit } \\
\text { Communicabl } \\
\text { South Africa }\end{array}$ & $\begin{array}{l}\text { spiratory } \\
\text { Meningitis, } \\
\text { ute for } \\
\text { Diseases, }\end{array}$ \\
\hline $\begin{array}{l}\text { Corresponder } \\
\text { June Williams }\end{array}$ & ce to: \\
\hline $\begin{array}{l}\text { Email: } \\
\text { june.williams }\end{array}$ & Dup.ac.za \\
\hline $\begin{array}{l}\text { Postal addres } \\
\text { PO Box } 12538 \\
\text { Onderstepoor } \\
\text { South Africa }\end{array}$ & 0110, \\
\hline $\begin{array}{l}\text { Dates: } \\
\text { Received: } 10 \\
\text { Accepted: } 18 \\
\text { Published: } 01 \\
\text { Republished: }\end{array}$ & $\begin{array}{l}\text { ept. } 2013 \\
\text { eeb. } 2014 \\
\text { Sept. } 2014 \\
\text { L Sept. } 2014\end{array}$ \\
\hline $\begin{array}{l}\text { How to cite th } \\
\text { Williams, J.H., } \\
\text { S., Human, S., } \\
\text { Venter, M., } 20 \\
\text { of fatal lineag } \\
\text { West Nile viru } \\
\text { in horses in Sc } \\
\text { Journal of the } \\
\text { Veterinary Ass } \\
\text { Art. \#1105, } 13 \\
\text { dx.doi.org/10 } \\
\text { v85i1.1105 }\end{array}$ & $\begin{array}{l}\text { is article: } \\
\text { Van Niekerk, } \\
\text { Van Wilpe, E. \& } \\
\text { 14, 'Pathology } \\
1 \text { and } 2 \\
\text { s infections } \\
\text { uth Africa', } \\
\text { South African } \\
\text { ociation 85(1), } \\
\text { pages. http:// } \\
4102 / \text { jsava. }\end{array}$ \\
\hline $\begin{array}{l}\text { Note: } \\
\text { This article wa } \\
\text { with the upda } \\
\text { for Figure } 8 \text {. }\end{array}$ & $\begin{array}{l}\text { s republished } \\
\text { ted footnote }\end{array}$ \\
\hline Read online: & $\begin{array}{l}\text { Scan this QR } \\
\text { code with your } \\
\text { smart phone or } \\
\text { mobile device } \\
\text { to read online. }\end{array}$ \\
\hline
\end{tabular}

Since 2007, West Nile virus (WNV) has been reported in South African horses, causing severe neurological signs. All cases were of lineage 2, except for one case that clustered with lineage 1 viruses. In the present study, gross and microscopic lesions of six South African lineage 2 -infected horses and the one lineage 1 case are described. Diagnoses were confirmed by real-time reverse-transcriptase polymerase chain reaction (RT-PCR) of central nervous system (CNS) tissue and one by RT-PCR of a brain virus isolate. The CNS of all cases was negative by RT-PCR or immunohistochemistry (IHC) for African horse sickness (AHS), equine encephalosis virus, equine herpes viruses 1 and 4, other zoonotic flaviviruses, alphaviruses, and shunivirus, and either by immunofluorescence or IHC for rabies. Gross visceral lesions were nonspecific but often mimicked those of AHS. The CNS histopathology of WNV lineage 2 cases resembled the nonsuppurative polioencephalomyelitis reported in the Northern Hemisphere lineage 1 and recent Hungarian lineage 2 cases. Occasional meningitis, focal spinal ventral horn poliomalacia, dorsal and lateral horn poliomyelitis, leucomyelitis, asymmetrical ventral motor spinal neuritis and frequent olfactory region involvement were also seen. Lineage 2 cases displayed marked variations in CNS lesion severity, type and distribution, and suggested various viral entry routes into the CNS, based on findings in experimental mice and hamsters. Lineage 1 lesions were comparable to the milder lineage 2 cases. West Nile virus IHC on CNS sections with marked lesions from all cases elicited only two antigen-positive cells in the olfactory cortex of one case. The presence in the CNS of T-lymphocytes, B-lymphocytes, plasma cells and macrophage-monocytes was confirmed by cluster of differentiation (CD) 3, CD20, multiple myeloma oncogene 1 (MUM1) and macrophage (MAC) 387 IHC.

\section{Introduction}

The Flavivirus West Nile virus (WNV) cycles naturally between birds and ornithophilic mosquitoes, especially Culex univittatus in South Africa (Jupp 2001). Lineage 1 WNV strains are known to be neuropathogenic and re-emergent in the Northern Hemisphere (Petersen \& Roehrig 2001), with the closely related, but less pathogenic subtype, Kunjin virus (Scherret et al. 2001) and its 2011 equine pathogenic variant $W_{N V}{ }_{N S W 2011}$ (Frost et al. 2012), which occurs in Australia. Lineage 2 WNV has been reported in South Africa since 2007-2008 as a cause of severe, emerging neurological disease in horses (Venter et al. 2009) and humans (Zaayman \& Venter 2012). Since 2004, it has been reported in Europe as a cause of severe illness or death in birds (Bakonyi et al. 2006; Danis et al. 2010), horses (Kutasi et al. 2009) and humans (Danis et al. 2010; Papa, Danis, Baka, Bakas, Douglas, Lytras et al. 2010; Papa, Perperidou, Tzouli \& Castilleti 2010; Papa, Bakonyi, Xanthopoulou, Vasquez, Tenorio \& Nowotny 2011; Papa, Danis, Tsergouli, Tsioka \& Gavana 2011; Papa, Xanthopoulou, Gewehr \& Mourelatos 2011; Platonov et al. 2008). Recent outbreaks of lineage 2 WNV in Romania in 2010 (Sirbu et al. 2011) and lineage 1 WNV in the United States of America (USA) in 2012 (Chung et al. 2013) have shown the incidence of neuroinvasive disease in humans to have risen to more than $50 \%$ of clinical cases. Horses and humans are similarly susceptible to WNV infection (Beasley 2005); however, horses have been afforded the opportunity of protection from WNV disease in the USA (Schuler et al. 2004), and more recently in Europe, since the introduction and registration of equine-specific lineage 1derived WNV vaccines.

In the South African survey of horses with neurological signs over the summer of 2007-2008 (Venter et al. 2009), seven horses were WNV lineage 2 positive by real-time reverse-transcriptase polymerase chain reaction (RT-PCR) (Zaayman et al. 2008), or WNV positive and analysed as lineage 2 by sequencing on blood, brain and/or spinal cord, and one by viral isolation. Five died or had to be euthanased, and gross and microscopic pathology descriptions of three were tabulated. These all had marked pulmonary, subcutaneous and/or intermuscular oedema and hydropericardium, with microscopic lesions, including those described for WNV lineage 1 (Venter et al. 2009). The microscopic pathology of one case was atypical, with peripheral spinal white matter Wallerian degeneration without inflammatory leucocyte infiltration, apart from

Copyright: @ 2014. The Authors. Licensee: AOSIS OpenJournals. This work is licensed under the Creative Commons Attribution License. 
phagocytosing myelinophages. One case was co-infected with African horse sickness virus (AHSV) (Venter et al. 2009).

During the autumn of 2010, 17 horses contracted neurological lineage 2 WNV in Hungary (Kutasi et al. 2011). Four of the five that died were examined histologically. Gross pathology was reported as 'negative' and histological lesions were found to be lymphoplasmacytic perivascular infiltration, gliosis with some focal neutrophil infiltration and neuronal degeneration. Lesions occurred mostly in the brain stem, medulla and grey matter of the spinal cord, with cervico-thoracic and lumbar region lesions being the most severe (Kutasi et al. 2011).

Detailed central nervous system (CNS) histopathology descriptions of WNV lineage 1-associated natural (Autorino et al. 2002; Bunning et al. 2002; Cantile et al. 2000; Cantile et al. 2001; Guillon et al. 1968; Schmidt \& El Mansoury 1963; Snook et al. 2001) or experimental (Bunning et al. 2002) equine cases in North Africa, Europe and North America have been published. Italian cases had mild rhombencephalitis and consistent spinal cord ventral horn non-suppurative polioencephalomyelitis, mostly of the thoraco-lumbar regions (Cantile et al. 2000; Cantile et al. 2001). A small comparative USA study showed moderate-to-severe multifocal perivascular lymphocytic rhombencephalitis, perivascular haemorrhages, scattered neutrophils and multifocal microgliosis; spinal cord examination in a single case had similar lesions (Cantile et al. 2001; Snook et al. 2001). Gross necropsy lesions were generally recorded as absent in the CNS and/or internal organs except for occasional cases (Autorino et al. 2002; Bunning, Wilson \& Bowen 2004; Cantile et al. 2000; Snook et al. 2001). Visceral lesions were reported in horses in Egypt (Schmidt \& El Mansoury 1963), Morocco (Tber Abdelhaq 1996) and Israel (Steinman et al. 2002); these included: pulmonary oedema and congestion (Tber Abdelhaq 1996); visceral congestion and occasional haemorrhages (Schmidt \& El Mansoury 1963); cardiac haemorrhages with mild pericardial effusion (Steinman et al. 2002); meningeal congestion, oedema and/or haemorrhages (Schmidt \& El Mansoury 1963; Tber Abdelhaq 1996) and lumbosacral spinal cord haemorrhage in one horse (Steinman et al. 2002). Spinal cord congestion with lumbar and thoracic segment haemorrhage were recorded in Italy (Cantile et al. 2000), with other authors recording occasional visible CNS petechiae in cut sections (Snook et al. 2001), perivascular haemorrhages (Cantile et al. 2001), and one described case of meningeal hyperaemia with subdural exudates and fibrin tags (Bunning et al. 2004).

Experimental infections of mice and hamsters have shown various routes of WNV CNS entry and transport after extra-cerebral inoculation, including: regional motor axonal transport from footpad or sciatic nerve inoculation into the ipselateral lumbar spinal cord ventral horn grey matter (Brown et al. 2007; Hunsperger \& Roehrig 2006; Kimura et al. 2010; Morrey, Siddharthan, Wang, Hall, Skirpstunas, Olsen et al. 2008; Samuel et al. 2007; Wang et al. 2009); transneuronal anterograde and retrograde intra-spinal transport (Wang et al. 2009); and multiple point entry into the spinal cord by haematogenous or neuroinvasive routes
(Brown et al. 2007). Rapid early neural transport of WNV during viraemia from the olfactory neurons into the olfactory bulbs (Brown et al. 2007; Hunsperger \& Roehrig 2006; Nir, Beemer \& Goldwasser 1965) with caudal progression in the brain (Nir et al. 1965) is also seen in flaviviral St Louis encephalitis infections in hamsters (Monath, Cropp \& Harrison 1983) and circulatory CNS WNV entry via the choroid plexus is recorded (Hunsperger \& Roehrig 2006). Dorsal sensory horn grey matter is occasionally infected after experimental sciatic nerve (Hunsperger \& Roehrig 2006; Wang et al. 2009) or ventral horn WNV infection (Wang et al. 2009). Neuronal tissue culture and hamster WNV experiments (Samuel et al. 2007) have concluded that WNV reaches neuronal or non-neuronal target cells by viral release extracellularly at distal axon sites, and that WNV uses specific pathways to enter the CNS, resulting in distinct disease phenotypes.

Confirmatory laboratory diagnostic criteria for WNV in patients with clinical neurological disease include isolation of virus, or detection of viral antigen or nucleic acid in tissue, blood or cerebrospinal fluid (CSF) (Beasley 2005). Real-time-PCR and nucleic acid sequencing is approximately 1000-fold more sensitive than viral culture for WNV detection (Hayes et al. 2005). Imunohistochemistry (IHC) with either monocloncal or polyclonal antibodies (Buckweitz et al. 2003a; Cantile et al. 2001; Castillo-Olivares \& Wood 2004; Kleiboeker et al. 2004; Pennick et al. 2012), and in situ hybridisation were found to be disappointing and unreliable for diagnosis in horses with WNV neurological disease (Cantile et al. 2001; Kleiboeker et al. 2004; Pennick et al. 2012), often being negative in the presence of positive PCR results (Buckweitz et al. 2003a). The amount of virus did not correlate with the degree of inflammation and virus distribution was often scant or localised.

This article gives details and illustrates the pathology and histopathology of six natural South African equine cases of WNV lineage 2 infection, including a more in-depth investigation of one of the three previously described cases (HS101/08) for comparison (Case 1) (Venter et al. 2009) and a peracute case (Case 5). The pathology of the recent 2010 WNV lineage 1 case from the Western Cape in a pregnant mare that aborted and then died (Venter et al. 2011), the first recorded in South Africa, is included (Case 7) for illustration and comparison with the lineage 2 cases.

\section{Materials and methods Clinical cases}

Seven horses with severe neurological signs, resulting in either death or euthanasia, underwent postmortem examination, and gross and microscopic pathology were investigated (Table 1). Cases from 2008-2011 occurred during early (Case 5) or late summer seasons, and were diagnosed with single WNV CNS infection (Table 1). One mare had recovered from AHS 10 days prior to developing neurological signs (Case 6). Case histories and clinical descriptions (Table 1) were supplied by the referring veterinarians and by some owners. Cases 1-6 were from the Gauteng highveld area of 
South Africa and Case 7 from the Western Cape. Some horses had been ante-mortally tested for some viruses in the blood (Table 2) and/or for viral antibodies.

\section{Gross postmortem examination}

Cases 1-6 were grossly examined at the Section of Pathology, Department of Paraclinical Sciences, Faculty of Veterinary Science, University of Pretoria (UP), Onderstepoort; and Case 7 by the referring private practitioner at Ceres in the Western Cape. Specimens from lumbar, thoracic and cervical spinal cord, as well as regions of the brain including the cerebellum, brain stem, midbrain, thalamus, hippocampus, olfactory lobe and surrounding cortex, were preserved in $10 \%$ neutral buffered formalin for a minimum of 24-48 h. Only formalin-preserved and fresh brain samples were received from Case 7. Duplicate samples of fresh CNS were placed on ice for RT-PCR (Cases 2-7), and in Case 1 for virus isolation with later RT-PCR of the isolate (Venter et al. 2009). Fresh brain was also submitted for rabies virus testing (Cases 1, 2 and 6). Samples of internal organs from Cases 1-6 and testicle of Cases 3 and 4 were also formalin fixed. Fresh samples of at least the spleen and lungs were collected for RT-PCR for AHS, equine encephalosis virus (EEV) and equine herpes virus- 1 and equine herpes virus- 4 (EHV) and for virus isolation (Cases 1, 3 and 6).

\section{Histopathology}

Selected regions of formalin fixed CNS (Table 1) and other tissues were prepared for routine wax embedding, $4 \mu \mathrm{m}$ sectioning, haematoxylin and eosin (HE) staining and light microscopic examination.

\section{Immunohistochemistry}

Immunohistochemical labelling of CNS tissues in sections showing the most pronounced lesions from Cases 1-7, plus one section of testicle with orchitis from Case 3 (Table 2) was performed using Thermo Scientific (Pierce Biotechnology, Illinois, USA) rabbit polyclonal WNV E antibody at dilution 1:50 according to the avidin-biotin complex technique (Haines \& Chelack 1991). Canadian origin (Dr Josepha DeLay, University of Guelph, Ontario, Canada) known RT-PCR positive lineage $1 \mathrm{WNV}$-infected avian heart and equine brain, as well as RT-PCR and IHC-positive BALBC mouse brain infected with South African neurovirulent SPU93-01 lineage $2 \mathrm{WNV}$, were simultaneously labelled as positive controls. The IHC protocol using the Thermo Scientific antibody was adjusted until the equine Canadian lineage 1 control tissue labelled similarly to the imported positive control section, which had been labelled with a different antibody obtained locally in the USA and after protocol suggestions from Dr DeLay. The same antibody dilution was used for mouse, avian and equine sections, but for mouse and horse the final Novored Substrate step was applied for $15 \mathrm{~min}$, using manual differentiation, as opposed to $1 \mathrm{~min}$ for the avian section. Immunohistochemistry using rabies polyclonal antibody (prepared by the late Dr Ken Charlton, Animal Diseases Research Institute, Ontario, Canada) at dilution 1:500, was performed on WNV positive controls as an irrelevant antibody with simultaneous labelling of a rabies-positive control, plus brain sections of Cases 3, 4, 5 and 7 to exclude rabies. Immunohistochemistry was similarly performed for EHV (antibody obtained from J. van der

TABLE 1: Signalment, clinical signs, comparative severity and distribution of central nervous system histological lesions of naturally occurring fatal equine West Nile virus positive Cases 1-7.

\begin{tabular}{|c|c|c|c|c|c|c|c|c|c|c|}
\hline Case & $\begin{array}{l}\text { Signalment } \\
\text { and date }\end{array}$ & Clinical signs & $\begin{array}{l}\text { Olfactory } \\
\text { region }\end{array}$ & Cerebral cortex & Thalamus & $\begin{array}{l}\text { Medulla } \\
\text { or brain } \\
\text { stem }\end{array}$ & Cerebellum & $\begin{array}{l}\text { Cervical } \\
\text { spinal cord } \\
\text { or brainstem }\end{array}$ & $\begin{array}{l}\text { Thoracic } \\
\text { spinal cord }\end{array}$ & $\begin{array}{l}\text { Lumbar } \\
\text { spinal cord }\end{array}$ \\
\hline Case 1* & $\begin{array}{l}\text { 8-yr TB gelding. } \\
\text { Mid-April } 2008\end{array}$ & $\begin{array}{l}\text { Recumbency, muscle } \\
\text { twitching, } \\
\text { loss of awareness, colic, } \\
\text { seizures, nystagmus, } \\
\text { died after } 4 \mathrm{~d} \text {. }\end{array}$ & + & + & + & + & + & + & + & $\begin{array}{l}++-++ \\
\text { meningeal } \\
\text { vasculitis }\end{array}$ \\
\hline Case 2* & $\begin{array}{l}\text { 11-yr wmbl gelding. } \\
\text { Mid-March } 2010\end{array}$ & $\begin{array}{l}\text { Sudden ataxia, depression, } \\
\text { tongue paralysis, falling, } \\
\text { fell dead after } 5 \mathrm{~d} \text {. }\end{array}$ & ++ & + & ++ & ++ & + & +-++ & ++ & $\begin{array}{l}\text { +++Haem, } \\
\text { ++ infl. }\end{array}$ \\
\hline Case $3^{*}$ & $\begin{array}{l}\text { 2-yr TB colt. Early } \\
\text { April } 2010\end{array}$ & $\begin{array}{l}\text { Difficulty rising, laminitic } \\
\text { stance, ataxia, recumbency, } \\
\text { euthanised after } 36 \mathrm{~h} \text {. }\end{array}$ & + & + & +++ & +++ & ++ & +++ & +-++ & $\begin{array}{l}+-+++ \text { focal } \\
\text { assym GM } \\
\text { VH malacia }\end{array}$ \\
\hline Case $4 *$ & $\begin{array}{l}\text { 4-yr Arab stallion. } \\
\text { Late April } 2010\end{array}$ & $\begin{array}{l}\text { Initial fever, ataxia, } \\
\text { hindlimbs weak, } \\
\text { recumbent, paddling } \\
\text { forelimbs, nystagmus, } \\
\text { euthanised at } 4 \mathrm{~d} \text {. }\end{array}$ & +++ & $+\mathrm{GM},++\mathrm{WM}$ & ++ & ++ & $\begin{array}{l}++ \\
\text { GM and WM, } \\
++ \text { meningitis }\end{array}$ & ++-+++ & ++ & + \\
\hline Case $5^{*}$ & $\begin{array}{l}\text { 17-yr Welsh X mare. } \\
\text { Early September } 2010\end{array}$ & $\begin{array}{l}\text { Progressive fever, lateral } \\
\text { recumbency, seizures, } \\
\text { mydriasis, loss of cranial } \\
\text { reflexes, tachypnoea, } \\
\text { gurgling, died after } 16 \mathrm{~h} \text {. }\end{array}$ & + & + & + & $\begin{array}{l}\text { choroid } \\
\text { plexus, + } \\
\text { PVC }\end{array}$ & - & PVhaem & PVhaem & - \\
\hline Case $6^{*}$ & $\begin{array}{l}\text { 7-yr Arab mare. } \\
\text { Late April } 2011\end{array}$ & $\begin{array}{l}\text { Progressive ataxia, } \\
\text { recumbent, } \\
\text { quadriparetic at } 3 \mathrm{~d} \text {, } \\
\text { assymetric forelimb } \\
\text { paresis. Euthanasia. }\end{array}$ & + & + & $\begin{array}{l}+ \\
\text { mild } \\
\text { meningitis }\end{array}$ & ++ & + & $\begin{array}{l}++-+++ \\
\text { assym sp } \\
\text { motor } \mathrm{N} \\
\text { neuritis }\end{array}$ & ++-+++ & ++-+++ \\
\hline Case $7 * *$ & $\begin{array}{l}6 \text {-yr pregnant TB } \\
\text { mare. May } 2010\end{array}$ & $\begin{array}{l}\text { Progressive ataxia, } \\
\text { recumbent, } \\
\text { quadriparetic at } 3 \mathrm{~d} \text {. } \\
\text { Euthanasia. }\end{array}$ & ++ & + & + & + & $\begin{array}{l}++ \\
\text { molecular } \\
\text { layer glial } \\
\text { flares }\end{array}$ & NE & NE & NE \\
\hline
\end{tabular}

yr, year; TB, Thoroughbred; wmbl, warmblood; X, crossbreed; d, days; h, hours; GM, grey matter; WM, white matter; PVC, perivascular cuffing; PV, perivascular; haem, haemorrhage; assym, assymetrical; sp, spinal; $\mathrm{N}$, nerve; $\mathrm{NE}$, not examined; infl, inflammation; $\mathrm{VH}$, ventral horn.

Subjective light microscopic determination of the severity of inflammatory lesions in each site was made: +, mild; ++, moderate; +++, marked; -, absent: where lesions were unique or outspoken they are written out.

$*$, WNV lineage 2; **, WNV lineage 1. 
Lugt, Onderstepoort Veterinary Institute [OVI]) at dilution 1:400, and the flavi-virus Wesselsbron (WESSV) (antibody obtained from J. van der Lugt, OVI) at dilution 1:500, on the brainstem, spinal cord and testicle of Case 3 and for EHV and AHS (polyclonal rabbit anti-AHSV serum at dilution 1:2000, from C. Hamblin, Institute for Animal Health, Pirbright Laboratory, United Kingdom) on brain, spinal cord, spleen, heart, liver, kidney and lung of Case 4, using simultaneously labelled known positive control sections for each. Immunohistochemistry for EEV (antiserum used at dilution 1:6000, obtained from C. Hamblin, Institute for Animal Health, Pirbright Laboratory, United Kingdom) and EHV were performed on the spleen, lung and lumbar spinal cord of Case 1 (Table 2).

Immunohistochemical cross-reactivity was tested on the respective control-positive sections for the two flaviviruses, WNV and WESSV virus, both present in South Africa; WESSV having been diagnosed previously by RT-PCR in two horses with neurological signs in South Africa, one of which died (Venter et al. 2008).

Sections with prominent inflammatory lesions from Cases 2, $3,4,6$ and 7 were selected and labelled with clone or cluster of differentiation (CD) 3 (polyclonal rabbit anti-human CD3, dilution 1:75; DakoCytomation, Glostrup, Denmark) for T-lymphocytes, CD20 (polyclonal rabbit Immunoglobulin G [IgG], catalog PA5-16701, dilution 1:1200; Thermo Scientific, Pierce Biotechnology, Rockford, Illinois, USA), which labels both plasma cells and B-lymphocytes, and multiple myeloma oncogene 1 (MUM1) protein (monoclonal mouse anti-human IgG, code M7259, dilution 1:25; DakoCytomation, Glostrup, Denmark), which principally labels the nuclei of plasma cells but also occasionally B-lymphocytes (Ramos-Vara, Miller \& Valli 2007). Additional labelling was done with macrophage (MAC) 387 (monoclonal mouse anti-human IgG, dilution 1:50; DakoCytomation, Glostrup, Denmark), which principally labels tissue histiocytes of myeloid origin and is expressed by circulating and emigrated neutrophils and monocytes, as well as a subset of reactive tissue macrophages. Immunohistochemistry for CD3, CD20 and MAC387 was performed using an LSAB+ kit (Dako, California, USA) with DAB+ as chromogen and haematoxylin counterstain. Multiple myeloma oncogene 1 IHC was done using a Novolink polymer detection system (Novocastra Laboratories, Newcastle on Tyne, United Kingdom), with $\mathrm{DAB}+$ as chromogen, and haematoxylin as counterstain. Simultaneously, lymphoid tissues of other species, as well as normal pharyngeal lymph node, thymic remnant and caecal mucosa known to be variably positive for each cell type, sampled from a young adult horse which was euthanised for non-infectious causes, were labelled as positive controls to ensure that the labelling was correct.

\section{Digital images}

Digital images were recorded during the majority of necropsies and preparation of formalin-fixed specimens using Panasonic Lumex FZ10 or FZ45 cameras (Panasonic Corporation, Ariake Tokyo, Japan). Images of histological lesions of all cases were taken on an Olympus BC50 (Olympus, Hamburg, Germany) microscope with attached CC12 soft imaging system, using analySIS software (Olympus, Hamburg, Germany).

\section{Viral diagnosis and viral isolation}

Rabies virus fluorescent antibody testing (FAT) on fresh composite brain smears was performed at the OVI for Cases 1,2 and 6 .

Fresh CNS tissues underwent RNA extraction and were tested by real-time RT-PCR for WNV by the method described by Zaayman, Human and Venter (2008), as well as for Flaviviridae family.

Central nervous system extracts of all cases were also RT-PCR tested to exclude the South African differential diagnoses of EEV, EHV and the orthobunyavirus shunivirus (Van Eeden et al. 2012), with the CNS of all cases being similarly tested for AHSV. Tests done for WNV, WESSV, Sindbis (SINV) and Middelburg viruses, AHS, EEV and EHV on various tissues in various cases are recorded in Table 2. They included viral isolation using standard techniques on either Vero

TABLE 2: Viruses that tested positive and negative in central nervous system and other tissues by various diagnostic tests in equine Cases 1-7.

\begin{tabular}{|c|c|c|c|c|c|c|c|}
\hline Case & $\begin{array}{l}\text { WNV CNS positive } \\
\text { RT-PCR*, Viral } \\
\text { solation, IHC }\end{array}$ & $\begin{array}{l}\text { AHSV, positive } \\
\text { RT-PCR* }\end{array}$ & $\begin{array}{l}\text { Rabies negative } \\
\text { FAT or IHC }\end{array}$ & $\begin{array}{l}\text { Alpha-family**, flavi-family**, } \\
\text { Shunivirus**, Negative } \\
\text { RT-PCR.*, WNV IHC }\end{array}$ & $\begin{array}{l}\text { AHSV Negative } \\
\text { VI, RT-PCR*, IHC }\end{array}$ & $\begin{array}{l}\text { EEV negative } \\
\text { VI, RT-PCR*, } \\
\text { IHC }\end{array}$ & $\begin{array}{l}\text { EHV }-1,-4 \text { negative } \\
\text { RT-PCR*, IHC }\end{array}$ \\
\hline 1 & WNV2*, VI & - & FAT & $\begin{array}{l}\text { CNS* all**, Spleen* WNV, } \\
\text { WNV IHC SC }\end{array}$ & $\begin{array}{l}\text { Blood*, CNS* VI spl, } \\
\text { lung, brain (Vero) }\end{array}$ & $\begin{array}{l}\text { CNS* VI spl, lung, } \\
\text { brain. IHC CNS, spl. }\end{array}$ & $\begin{array}{l}\text { Blood* CNS* VI spl, lung, } \\
\text { CNS. IHC, VI CNS, spl }\end{array}$ \\
\hline 2 & WNV2* & - & FAT & CNS* all**, WNV IHC SC & $\mathrm{CNS}^{*}$ & CNS* & $\mathrm{CNS}^{*}$ \\
\hline 3 & WNV2* & - & IHC & $\begin{array}{l}\text { CNS* all**, IHC WNV or } \\
\text { WESSV test., WNV IHC SC }\end{array}$ & $\begin{array}{l}\text { CNS* spl*,lung* } \\
\text { VI spl, lung(BHK) }\end{array}$ & $\begin{array}{l}\text { CNS* VI spl, Lung. } \\
\text { Spl*, lung* }\end{array}$ & CNS* IHC CNS, testicle \\
\hline 4 & $\begin{array}{l}\text { WNV2*, IHC olf. } \\
\text { cortex }\end{array}$ & - & $\mathrm{IHC}$ & CNS* all** & $\begin{array}{l}\text { CNS* IHC CNS, } \\
\text { organs }\end{array}$ & CNS* & CNS* IHC CNS, organs \\
\hline 5 & WNV2* & - & $\mathrm{IHC}$ & $\begin{array}{l}\text { CNS* all**, Blood*, WNV } \\
\text { IHC, olf.cort. }\end{array}$ & $\begin{array}{l}\text { CNS*,spl*, } \\
\text { lung*VI spl, } \\
\text { lung (BHK) }\end{array}$ & CNS* VI spl, lung & CNS*, spl*, lung* \\
\hline 6 & WNV2* & $\begin{array}{l}\text { spleen or } \\
\text { lung AHSV* }\end{array}$ & FAT & $\begin{array}{l}\text { CNS* all**, WNV IHC, } \\
\text { olf. cort. }\end{array}$ & $\begin{array}{l}\text { CNS* VI spl, } \\
\text { lung(BHK) }\end{array}$ & $\begin{array}{l}\text { CNS*, spl*, lung* } \\
\text { VI spl, lung }\end{array}$ & CNS* \\
\hline 7 & WNV1* & - & $\mathrm{IHC}$ & $\begin{array}{l}\text { Brain* all**, WNV IHC, } \\
\text { olf. cort. }\end{array}$ & Brain* & Brain* & Blood*, Brain* \\
\hline
\end{tabular}

WNV, West Nile virus; CNS, central nervous system; RT-PCR, reverse-transcriptase polymerase chain reaction; IHC, immunohistochemistry; VI, virus isolation; olf, olfactory; AHSV, African horse sickness virus; FAT, fluorescent antibody test; sc, spinal cord; WESSV, Wesselsbron virus; test, testicle; cort, cortex; spl, spleen; Vero, Vero cells; BHK, baby hamster kidney cells; EEV, equine encephalosis virus; EHV, equine herpes virus.

*, RT-PCR; **, RT-PCR for alphavirus and flavivirus families and shunivirus. 
cells (Case 1), or baby hamster kidney (BHK) cells; IHC and RT-PCR on blood drawn ante-mortally (Cases 1 and 7) or directly post-mortally (Case 5), and on organs other than CNS. The serum of Case 1 was tested ante-mortally for antibodies to AHS, EEV, WNV and EHV-1 and EHV-4 (Venter et al. 2009).

RNA extracts of the CNS from all cases, and blood of Case 5, were screened with an alphavirus family-specific RT-PCR, as described by Sanchez-Seco et al. (2001).

\section{Other}

Due to the very early seasonal, unexpected occurrence and peracute nature of Case 5, this mare was also tested for organophosphate, organochlorine and carbamate pesticides in stomach content and for brain lead concentration at the OVI Toxicology Department. Aerobic and anaerobic bacterial cultures were performed on lung, spleen, brain and jejunal content, as well as Salmonella culture of the jejunum. Transmission electron microscopy (TEM) was done on testicular tissue from Case 3 by deparaffinising wax block material (Van den Berg Weermans \& Dingemans 1984). Ultra-thin resin sections were examined with a Philips CM10 transmission electron microscope (Philips Electron Optical Division, Eindhoven, The Netherlands) operated at $80 \mathrm{kV}$. Digital images were captured with a Megaview III side-mounted digital camera (Olympus Soft Imaging Solutions $\mathrm{GmbH}$, Münster, Germany) and iTEM software (Olympus Soft Imaging Solutions $\mathrm{GmbH}$, Münster, Germany).

\section{Results \\ Clinical signs}

Signalment, clinical signs, final outcome of the case (death or euthanasia) and date of occurrence for Cases 1-7 are tabulated (Table 1).

\section{Viral diagnoses and genotyping}

All cases were RT-PCR positive for $\mathrm{WNV}$ in the brain (Cases 1, 2, 4-7) and/or spinal cord (Cases 1-4 and 6) (Table 2). Tissue culture from the brain of Case 1 grew virus, which on RT-PCR was WNV lineage 2, whereas the spleen and lung were virologically negative (Venter et al. 2009). Antemortal serological testing of Case 1 by enzyme-linked immunosorbent assay (ELISA) showed antibodies for AHS (1:8), EEV (1:4) and EHV-1 (1:8), with WNV and EHV-4 being negative.

Cases 1-6 were shown to be WNV lineage 2, and Case 7 was lineage 1 (Venter et al. 2011) CNS positive by real-time RT-PCR. The WNV titre of Case 5 was low and positive only in the olfactory cortex and thalamic regions, with all other areas of brain and spinal cord being negative.

All other tests were negative except for the spleen and lung of Case 6, which were RT-PCR positive for AHS but from which viral isolation was negative (Table 2). This mare had previously been diagnosed with AHS in the blood and she had clinically recovered. Control-positive sections for the rabies, WNV, WESSV, EEV, EHV and AHS antibodies were all labelled correctly by IHC. The WESSV and WNV antibodies did not cross-react.

In the CNS sections selected from areas of marked lesions from all cases (Table 2), IHC for WNV labelled positively a single glial cell central to a glial nodule and one small cortical neurone in the olfactory cortex of Case 4 , and three glial cells in the Canadian lineage $1 \mathrm{WNV}$ equine brain control. In the other control-positive sections, WNV antigen labelled in several avian cardiomyocytes and mouse brain neurons, respectively.

\section{Other tests}

In Case 5, brain lead measured $0.75 \mathrm{mg} / \mathrm{kg}$ (toxic levels range from $3.00 \mathrm{mg} / \mathrm{kg}-30.00 \mathrm{mg} / \mathrm{kg}$ ) (Puls 1994), stomach content was negative for common pesticides, and aerobic and anaerobic bacterial culture from the brain, lung and spleen were negative after $72 \mathrm{~h}$ of incubation, with jejunal content having normal bacterial flora and Salmonella species culture negative. Ultrastructural examination of the testicular tissue from Case 3 did not identify viral particles in the $50 \mathrm{~nm}$ size range of $\mathrm{WNV}$, nor amorphous bodies or crystalline structures that might have suggested pre-particulate aggregates of WNV (Ghadially 1988; Steele et al. 2000).

\section{Gross lesions}

The gross lesions common to most cases included: variable external self-induced trauma, especially to bony prominences; mild-to-severe pulmonary oedema and congestion; variable serosanguinous hydropericardium; occasional hydrothorax or ascites; subcutaneous and intermuscular oedema, mostly of the neck but also occasionally of hindquarters (Case 1) and genital region (Cases 1 and 3); oedema of the supraorbital fossae (Cases 1, 3, 5 and 6) (Figure 1); white or blood-stained foam lining the distal trachea (Cases 2 and 6), filling the tracheal lumen (Cases 1, 3 and 4) or exuding from the nostrils (Case 3) (Figure 1) and mild haemorrhages on serosal surfaces, especially of the heart.

Case 5 had epicardial, subpleural, diaphragmatic, mesenteric, tracheal mucosal, adrenal cortical and bronchial lymph node petechiae, ecchymoses and suggilations and exhibited moderate visceral cyanosis and dark congestion.

The tongue of Case 2 was flaccid, oedematous and pale with a single dorsal epidermal vesicle of approximately $2 \mathrm{~cm}$ diameter. Case 6 had multifocal oral and lingual ulcerations of uncertain origin and showed mild pulmonary oedema.

Macroscopic CNS lesions included: ecchymotic haemorrhages of lumbar spinal grey and white matter and diffuse meningeal subarachnoid lumbar spinal haemorrhage (Case 2); diffuse dorsal lumbar and thoracic meningeal subarachnoid haemorrhage (Case 6) and/or small petechiae and markedly distended vessels in the spinal cord and brain grey and/or white matter, with predominance in the lower brain centres (Cases 2-4) (Figure 2). The CNS was otherwise variably congested. 


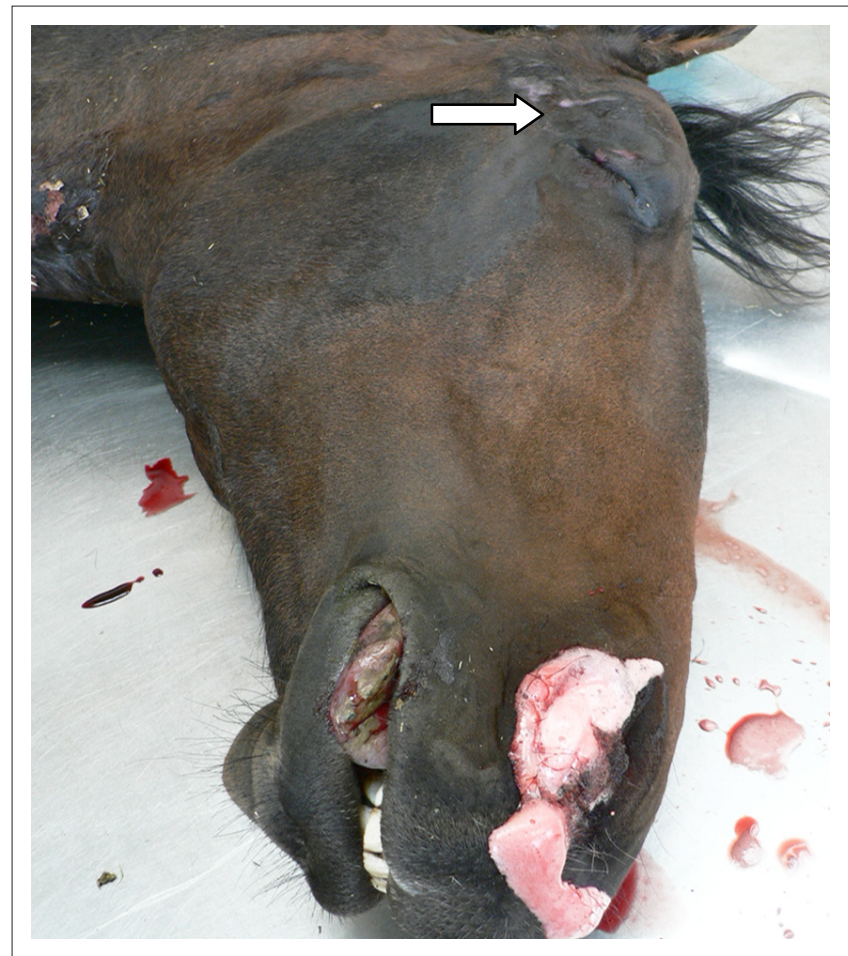

Source: Image was taken by June Williams

FIGURE 1: Head of lineage 2 West Nile virus-infected Case 3 demonstrating oedema of the supraorbital fossa (arrow) and blood-tinged foam at nostrils.

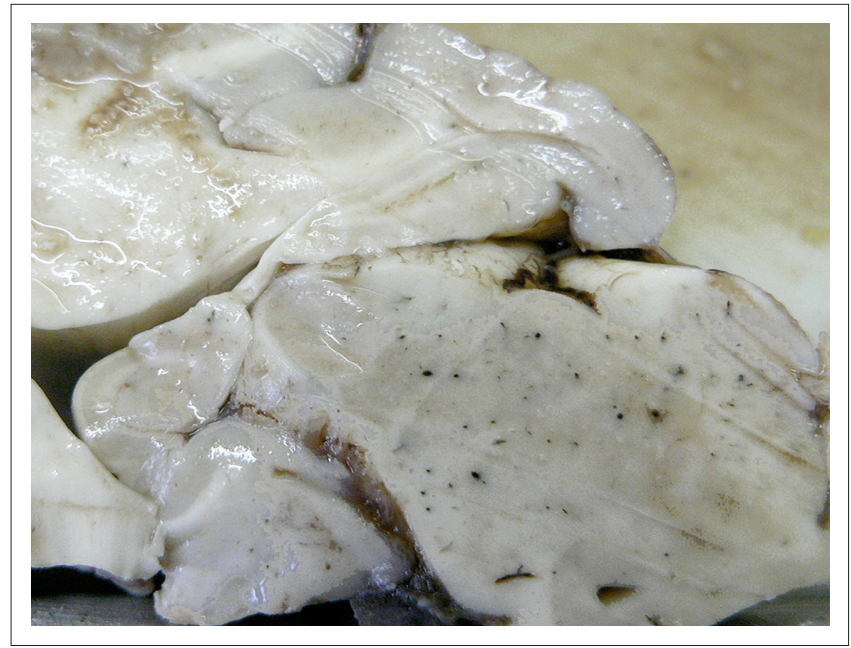

Source: Image was taken by June Williams

FIGURE 2: Thalamus of lineage 2 West Nile virus positive Arabian stallion Case 4 showing macroscopic vascular distension and petechiae.

\section{Histologic findings}

Table 1 gives information for comparison of severity and distribution of CNS lesions common to all cases and additional or severe lesions specific to certain cases. Table 3 shows the results of IHC for identification of T-lymphocytes, B-lymphocytes, plasma cells and macrophage-monocytes in selected CNS sections from five of the cases.

\section{Spinal cord}

Lesions were mostly asymmetrical, not always bilateral, and included perivascular petechiae in the meninges, white and grey matter, and massive lumbar cord meningeal (Cases 2

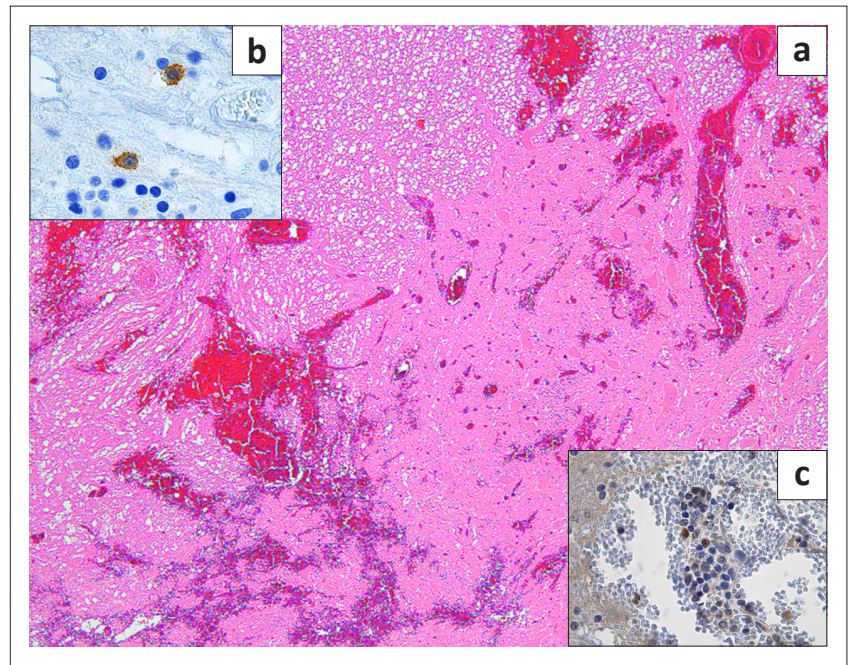

Source: Image was taken by June Williams

HE $\times 40$.

FIGURE 3: (a) Lumbar spinal cord of lineage 2 West Nile virus Case 2 with severe multifocal to coalescing haemorrhage involving white and grey matter. (b) Case 2 cauda equina spinal cord ventral horn grey matter with two immunohistochemistry cluster of differentiation 20+ (brown) labelled plasma cells in parenchyma. Cluster of differentiation 20 immunoperoxidase using LSAB+ $\mathrm{DAB}$ as chromogen and haematoxylin counterstain $x$ 1000. (c) Case 2 cauda equina grey matter perivascular immunohistochemistry Multiple myeloma oncogene1+ plasma cells (dark brown-black staining round nuclei). Multiple myeloma oncogene 1 immunoperoxidase using polymer $D A B$ as chromogen and haematoxylin counterstain $\times 1000$.

and 6) and intramedullary haemorrhages (Case 2) (Figure 3) with vascular congestion, especially of the grey matter but also focally in the white matter. Variable perivascular cuffing - with lymphocytes, plasma cells, occasional macrophages and neutrophils - was seen in HE sections and confirmed by specific IHC in most of the sections of cases selected for IHC (Tables 1 and 3) (Figures 3-9 with inserts of IHC images from Cases 2, 3, 4, 6 and 7).

Other lesions included: diffuse grey matter gliosis, glial nodules with a few neutrophils, scattered apoptotic glial cells and peri-central canal gliosis (lumbar cord of Cases 1 and 2). All lesions were most prominent in the ventral horn grey matter, sometimes occurred in dorsal and lateral horns and were sporadic in the white matter and meninges. Distribution and severity of lesions varied markedly between cases (Table 1). Nonsuppurative poliomyelitis was prominent in the cauda equina of Case 2. Occasional segmental lumbar spinal meningeal vascular-wall necrosis was seen (Case 1) (Venter et al. 2009).

Focal, unilateral lumbar-cord ventral horn poliomalacia, within which were Gitter cells, other glial cells, lymphocytes, plasma cells and some necrotic neurones, were found in Case 3 (Figure 4). Unilateral, ventral motor spinal nerve neuritis, associated with multifocal axon and myelin degeneration and mononuclear inflammatory cell infiltration, was found in the distal cervical cord of Case 6 (Figure 5).

\section{Brain and cerebellum}

Lesions resembling those in the spinal cord, as well as occasional scattered foci of mononuclear meningitis involving the cerebrum (mild in Cases 2 and 6) and/or cerebellum (moderate in Case 4) were also seen (Figure 6). 
Olfactory lobe and surrounding frontal-cortex multifocal grey matter glial nodules containing necrotic neutrophils were found prominently in Case 4 (Figure 7), as well as moderate-to-severe white matter perivascular mononuclear cuffing, meningeal congestion and vascular leucostasis. Case 4 also exhibited cerebellar molecular layer glial 'flares' (Figure 6). Cases 1, 2, 5 and 7 had moderate frontal cortex and olfactory lobe lesions. Some areas of grey matter of Case 6 exhibited neuronal satellitosis. Leucoencephalitis,

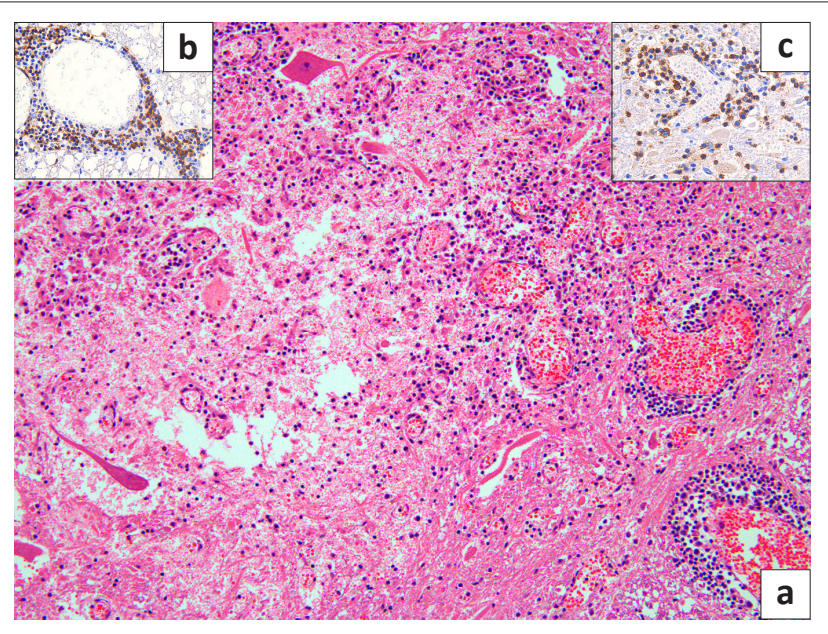

Source: Image was taken by June Williams

HE $\times 200$.

FIGURE 4: (a) Lumbar spinal cord of lineage 2 West Nile virus Case 3 with unilateral ventral horn focal poliomalacia, neurone necrosis and perivascular mononuclear cuffing. (b) Case 3 lumbar spinal cord white matter vessel with many immunohistochemistry cluster of differentiation 20+ (brown cytoplasm) B-lymphocytes or plasma cells amongst the perivascular mononuclear infiltrate. Cluster of differentiation 20 immunoperoxidase using LSAB+DAB as chromogen and haematoxylin counterstain $x 400$. (c) Case 3 lumbar spinal cord ventra horn grey matter vessel with perivascular and scattered immunohistochemistry cluster of differentiation 3+ (brown) T-lymphocytes. cluster of differentiation 3 immunoperoxidase using LASB+ DAB as chromogen and haematoxylin counterstain $\times 400$

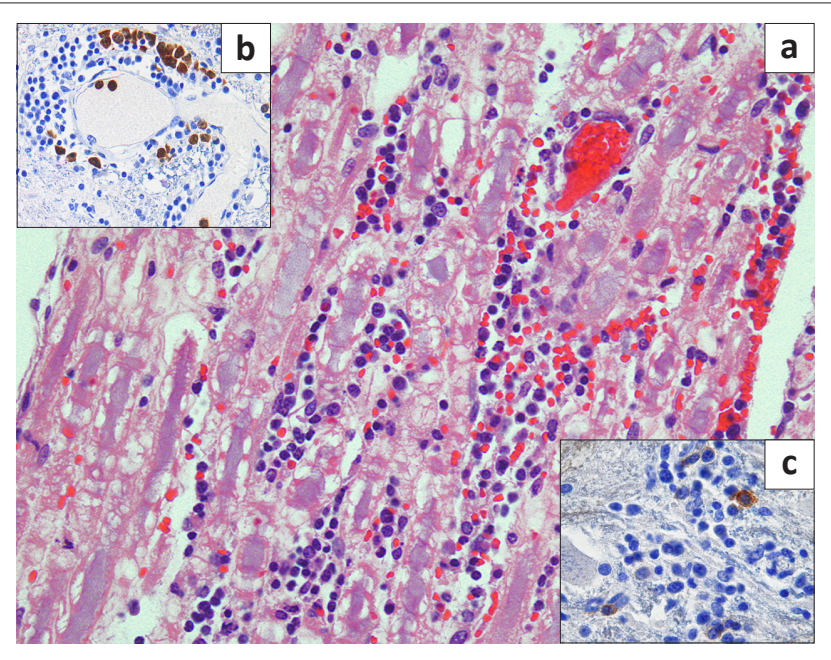

Source: Image was taken by June Williams

HE $\times 400$.

FIGURE 5: (a) Distal cervical spinal cord in lineage 2 West Nile virus Case 6 locally-extensive mononuclear ventral motor spinal neuritis. (b) Case 6 lumbar spinal cord ventral horn grey matter with perivascular Macrophage 387+ (brown) labelled monocyte-macrophages and some neutrophils. Macrophage 387 immunoperoxidase using LSAB+ DAB as chromogen and haematoxylin counterstain $x 400$. (c) Case 6 lumbar cord grey matter cluster of differentiation $20+$ (brown) labelled B-lymphocytes or plasma cells in grey matter. Cluster of differentiation 20 immunoperoxidase using $L S A B+D A B$ as chromogen and haematoxylin counterstain $\times 1000$ mainly affecting the thalamus, midbrain, pons and brainstem, was relatively more pronounced in Cases 2-4 (Figure 8 and 6). Inflammatory lesions of lineage $1 \mathrm{WNV}$ (Case 7) were, by comparison, mild (Figure 9).

Occasional small vessels were found with mild perivascular mononuclear cuffing in the frontal and parietal cortices, and in the choroid plexus (Figure 10) of Case 5, with olfactory lobe and frontal cortical white matter oedema and white matter perivascular petechiae.

The results of the IHC labelling of selected sections from each of Cases 2-4, 6 and 7, revealed the CNS inflammatory leucocyte response to be represented mostly by CD3-positive

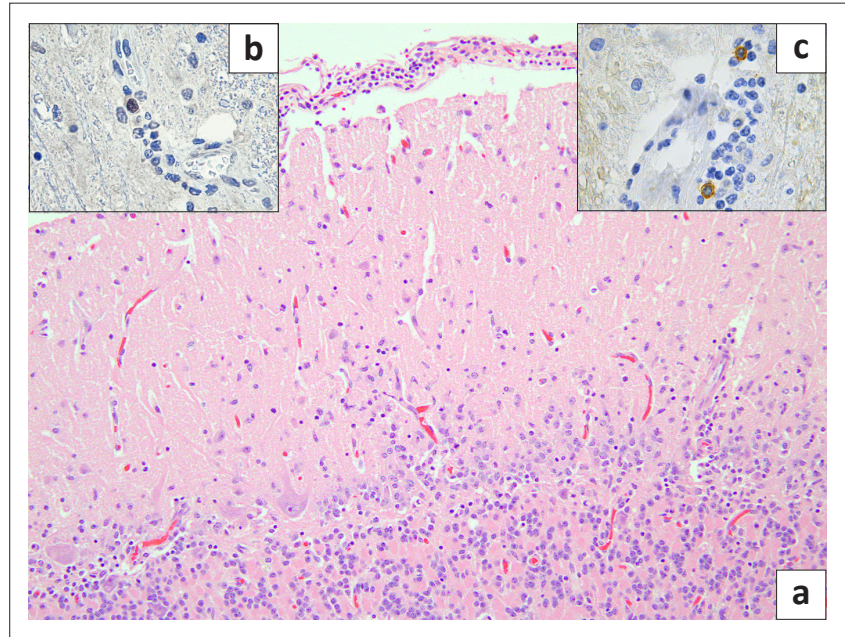

Source: Image was taken by June Williams

HE $\times 200$.

FIGURE 6: (a) Cerebellum of Case 4 showing molecular layer gliosis with glial flares and intermittent mild mononuclear meningitis. (b) Case 4 brainstem vessel with a perivascular immunohistochemistry multiple myeloma oncogene $1+$ (dark nucleus) plasma cell. Multiple myeloma oncogene 1 immunoperoxidase using polymer DAB as chromogen and haematoxylin counterstain $x$ 1000. (c) Case 4 brainstem vessel perivascular immunohistochemistry cluster of differentiation $20+$ (brown) B-lymphocytes/plasma cells. Cluster of differentiation 20 immunoperoxidase using LSAB+ DAB as chromogen and haematoxylin counterstain $\times 1000$.

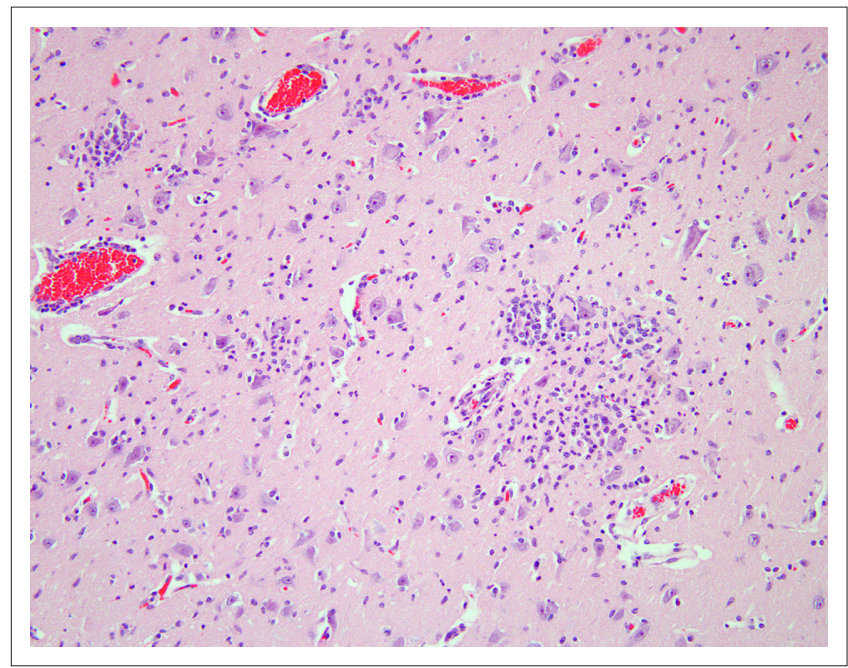

Source: Image was taken by June Williams

HE $\times 200$.

FIGURE 7: Olfactory cortex of lineage 2 West Nile virus infected Case 4 multifocal glial nodules, diffuse gliosis and perivascular lymphoplasmacytic and histiocytic cuffing. 
T-lymphocytes, variable MAC387-positive macrophages and neutrophils, but also by few-to-several scattered CD20-positive cells (labelling both B-lymphocytes and plasma cells) and MUM1 protein nucleus-positive plasma cells (Table 3). All the cell types were variably present in the perivascular cuffs and/or scattered in the parenchyma in and around the foci of gliosis in both the spinal cord (Case 3) (Figure 4 inserts) and brain, especially where the inflammation was prominent, as in Case 4 (Figure 8 inserts). Where inflammation was mild, as in the brain of

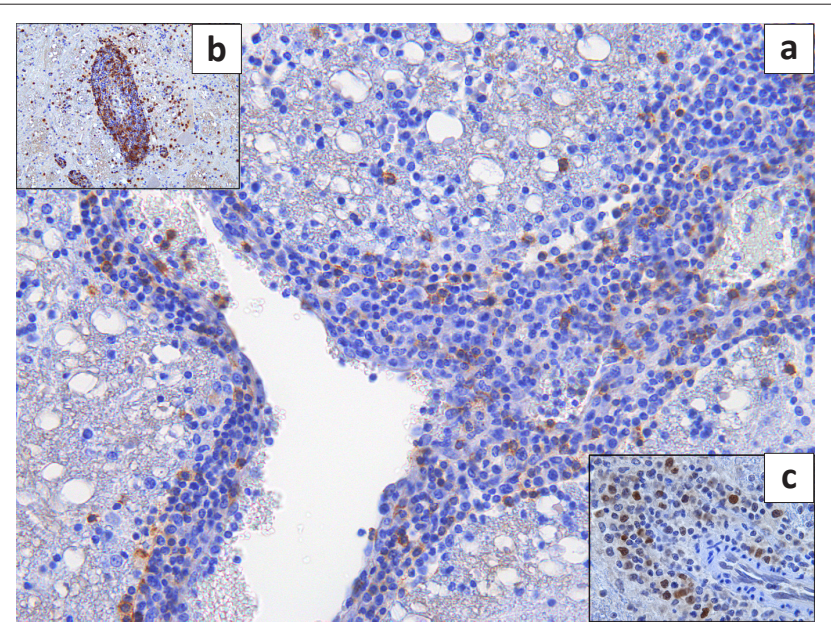

Source: Image was taken by June Williams

FIGURE 8: (a) Brain stem of lineage 2 West Nile virus infected Case 3 with severe perivascular cuffing with immunohistochemistry cluster of differentiation 20+ (brown) B-lymphocytes or plasma cells scattered in the cuff and the parenchyma. Cluster of differentiation 20 immunoperoxidase using $L S A B+D A B$ as chromogen and haematoxylin counterstain $\times 400$. (b) Case 3 brainstem with perivascula and parenchymal cluster of differentiation $3+$ (brown) T-lymphocytes. Cluster of differentiation 3 immunoperoxidase using LASB+ DAB as chromogen and haematoxylin counterstain $\times 200$. (c) Case 3 brainstem perivascular multiple myeloma oncogene $1+$ labelled (dark nuclei) plasma cells. Multiple myeloma oncogene 1 immunoperoxidase using polymer DAB as chromogen and haematoxylin counterstain x 1000 .

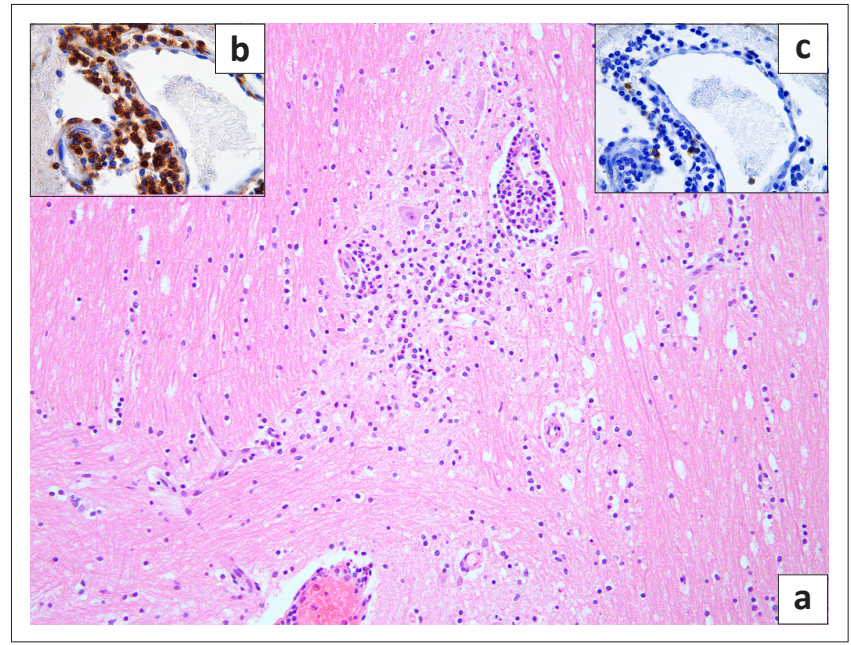

Source: Image was taken by June Williams

HE $\times 200$

FIGURE 9: (a) Thalamus of lineage 1 West Nile virus Case 7 showing perivascular lymphoplasmacytic cuffing and multifocal glial nodules, (b) Case 7 thalamus with perivascular cluster of differentiation $3+$ (brown) T-lymphocytes. Cluster of differentiation 3 immunoperoxidase using LASB+ DAB as chromogen and haematoxylin counterstain $\times 1000$. (c) Case 7 thalamus with perivascula cluster of differentiation 20+ (brown) B-lymphocytes or plasma cells. Cluster of differentiation 20 immunoperoxidase using $L S A B+D A B$ as chromogen and haematoxylin counterstain $\times 1000$.

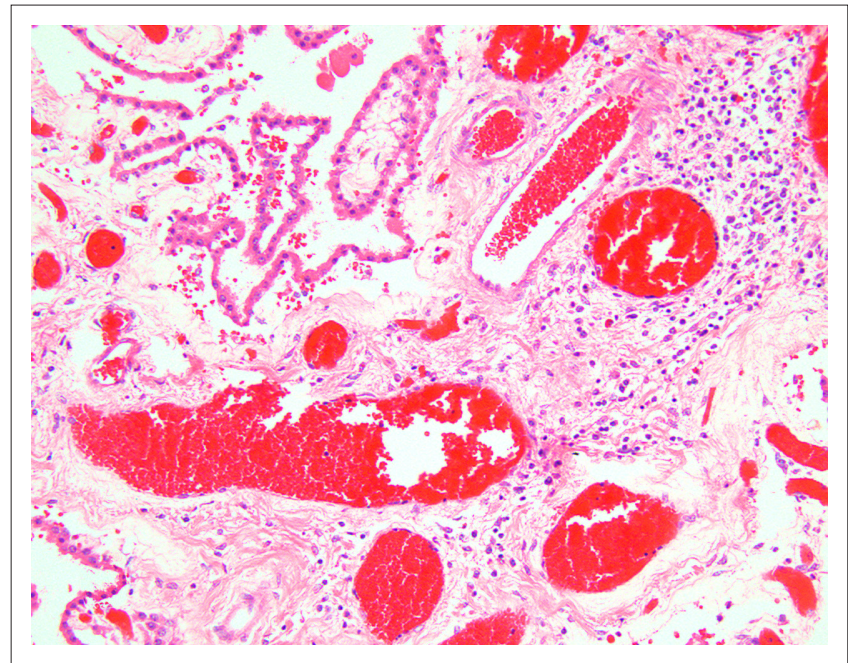

Source: Image was taken by June Williams

HE $\times 200$.

FIGURE 10: Choroid plexus of acute lineage 2 West Nile virus Case 5 showing multifocal perivascular inflammatory mononuclear inflammation and congestion.

the lineage 1 Case 7 , there were almost exclusively CD3+ lymphocytes with only occasional CD20+ cells (Figure 9 inserts). The normal equine lymph node labelled with CD20 had relatively feint cytoplasmic labelling of cortical follicular B-lymphocytes and more-intense cytoplasmic labelling of the medullary cord plasma cells. Similarly, some of the CD20+ cells in Case 6 CNS sections had variably intense labelling. Plasma cell nuclei, which were MUM1 protein-positive in the normal lymph node, labelled more intensely than those in the CNS. Results of the CNS mononuclear inflammatory cell IHC labelling in Cases 2-4, 6 and 7 are recorded in Table 3.

\section{Other lesions}

Case 3 demonstrated severe genital oedema and multifocal lymphoplasmacytic degenerative orchitis. The testicles of Case 4 , by comparison, were histologically normal and undergoing spermatogenesis. The lingual vesicle of Case 2 was associated with submucosal perivascular mononuclear inflammation and underlying marked non-inflammatory inter-myofibre lingual oedema, with occasional segmental myolysis. This horse also had mild nephrosis, mild periportal hepatic hydropic vacuolisation and occasional small foci of hepatocyte necrosis. Case 6 had midzonal hepatocyte hydropic changes and multifocal mild necrosis, with the associated presence of macrophages. The lingual ulcers of Case 6 were superficially contaminated with debris and bacteria, with an underlying necropurulent reaction zone extending deep into the submucosa and muscle layers; this mare also had occasional mild interstitial lymphoplasmacytic nephritis.

\section{Discussion}

The present study confirms the South African field strains of WNV lineage 2 to be neuroinvasive and highly pathogenic in horses. It also describes and illustrates the macroscopic and microscopic lesions. The lineage 2 cases show much variation of severity, distribution and type of CNS microscopic lesions between and within individual cases, but the majority of 
TABLE 3: Specific immunohistochemical labelling of inflammatory cells in areas of intense immunopathology in the central nervous system of West Nile virus-infected horses.

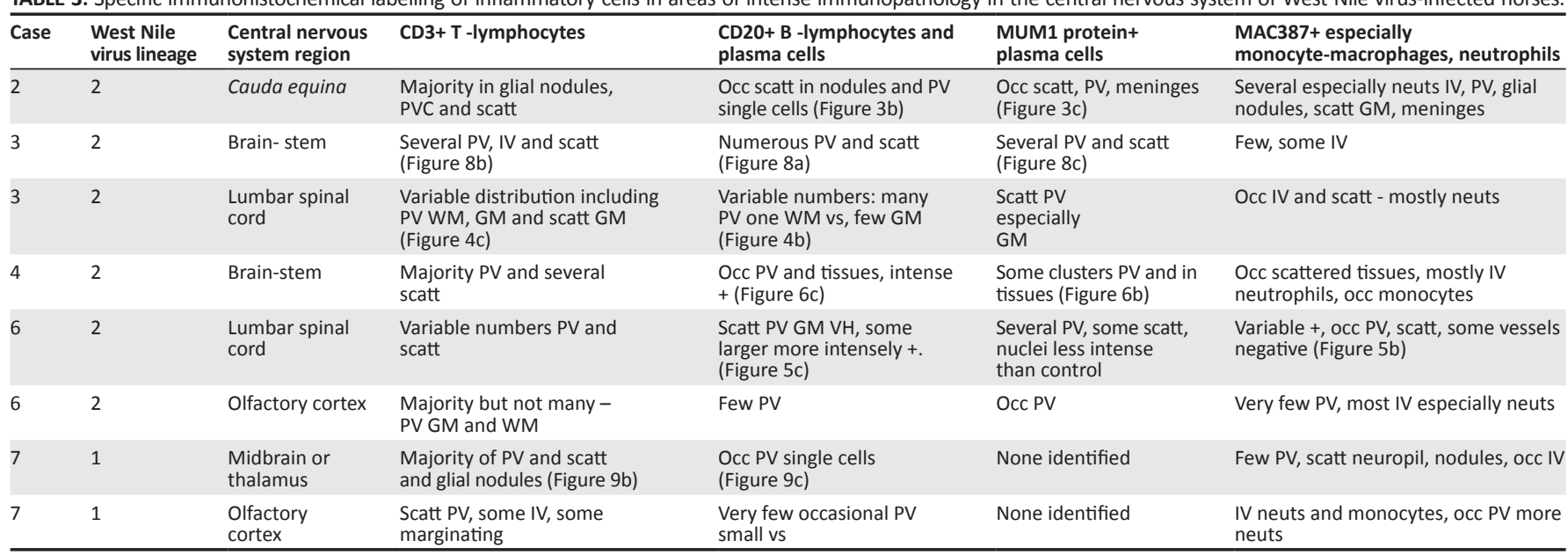

$\mathrm{CD}$, clone or cluster of differentiation; +, positive; PVC, perivascular cuffing; PV, perivascular; IV, intravascular; scatt, scattered; WM, white matter; GM, grey matter; vs, vessels; occ, occasional; VH, ventral horn; MUM1, multiple myeloma oncogene1; MAC, macrophage; neuts, neutrophils.

lesions are similar to those reported with lineage $1 \mathrm{WNV}$ (Bunning et al. 2002; Cantile et al. 2000, 2001; Guillon et al. 1968; Schmidt \& El Mansoury 1963; Snook et al. 2001) and Hungarian lineage 2 cases (Kutasi et al. 2011). Olfactory region encephalitis and asymmetrical spinal neuritis suggest, but do not prove, varying neural routes of entry of WNV into the CNS, as has been previously found by experimental extra-cerebral inoculation of WNV in mice and hamsters (Brown et al. 2007; Hunsperger \& Roehrig 2006; Kimura et al. 2010; Morrey, Siddharthan, Wang, Hall, Skirpstunas, Olsen et al. 2008; Samuel et al. 2007; Wang et al. 2009).

All positive RT-PCR products were confirmed by sequencing of the NS5 region (genome positions 9091-9191), except for Case 5, in which viral load was too low, indicating the value of the nested real-time PCR in distinguishing between lineages. Previous phylogenetic analysis has shown that the lineage $1 \mathrm{WNV}$ identified in Case 7 is similar to a North African Tunisian strain (PAH001) isolated in 1997 from a person who died of neurological disease, with E-protein analysis grouping it with isolates from Russia and Tunisia (Venter et al. 2011).

The unilateral ventral motor spinal neuritis at the region of pectoral limb supply in Case 6 corresponded with her clinical asymmetrical forelimb paresis. This suggests ascending motor neural transmission of virus from ipsilateral cutaneous inoculation by infected mosquitoes, as found after experimental cutaneous inoculation in mice and hamsters (Brown et al. 2007; Hunsperger \& Roehrig 2006; Kimura et al. 2010; Morrey, Olsen, Siddharthan, Motter, Wang, Taro et al. 2008; Wang et al. 2009). This pathogenesis, as well as multiple point entry into the spinal cord (Brown et al. 2007), could, if verified, explain the clinical signs of 'lameness' and/or muscle twitching seen in one or more single limbs of some horses with WNV neurological infection, and also the variation in CNS microscopic lesion distribution and severity in the current series of natural cases.

Olfactory lobe lesions were suggestive of olfactory neuroepithelial entry of circulating WNV into the CNS, particularly in Case 5, which was peracute, and was real-time RT-PCR positive only from the olfactory cortex and thalamus, with more caudal regions of the CNS and spinal cord being negative. Microscopic lesions in this case were similarly acute and found only in the cranial half of the cerebral cortex, with perivascular leucocyte infiltration of ventricular choroid plexus vessels suggesting also, but not proving, a possible vascular route of entry.

The 2010 late summer cases had macroscopically visible vascular lesions in the CNS and prominent microscopic lesions. The lineage $1 \mathrm{WNV}$ case lesions were mild in comparison, but also included olfactory cortex lesions. All horses showed severe neurological signs despite the varying severity of histological lesions.

In the present study, IHC was confirmed to be a very poor diagnostic tool for equine WNV, as reported previously with WNV lineage 1 (Buckweitz et al. 2003b; Bunning et al. 2002; Cantile et al. 2001; Castillo-Olivares \& Wood 2004; Kleiboeker et al. 2004; Pennick et al. 2012), and RT-PCR of the CNS was used to confirm infection (Pennick et al. 2012). In WNV neuroinvasive infections, horses typically exhibit marked inflammation in the presence of little antigen; this is most likely due to a large immunopathology component (Cantile et al. 2001; Castillo-Olivares \& Wood 2004; Lim et al. 2011). This is in contrast with species like hamsters, where CNS inflammatory change is minimal in the presence of plentiful antigen (Castillo-Olivares \& Wood 2004). Electron microscopy has similarly shown that intracellular WNV particles are rare in WNV-infected IHC or immunolabelled tissues of birds and mice (Hayes et al. 2005; Steele et al. 2000; Williams et al. 2014) and that what labels is flavivirus-associated pre-particulate crystalline or paracrystalline amorphous bodies or dense membrane vesicular structures (Ghadially 1988; Steele et al. 2000).

The CD20 and MUM1 protein IHC confirms the presence of plasma cells and B-lymphocytes in the inflammatory response in the CNS of WNV lineage 1 and 2 infected horses. 
There were few-to-moderate numbers in comparison with a predominance of CD3-positive T-lymphocytes, fewer MAC387-positive monocyte-macrophages and variable numbers of neutrophils. Of the few authors reporting pathology of WNV-infected horses, three recorded perivascular lymphoplasmacytic and histiocytic cuffing in the CNS (Autorino et al. 2002; Cantile et al. 2000; Kutasi et al. 2011), whilst most others mentioned only lymphocytes and histiocytes (Bunning et al. 2002; Castillo-Olivares \& Wood 2004; Guillon et al. 1968; Snook et al. 2001). A single IHC study conducted on CNS inflammatory cells in six horses from Italy identified 'almost exclusively' small T-lymphocytes (CD3 positive) with occasional MAC387-positive macrophages and no BLA.36-positive B-lymphocytes (Cantile et al. 2001). In human WNV studies where histopathology was investigated in six immunocompromised patients (Armah et al. 2007), CD3-positive T-lymphocytes were found variably in the parenchyma of the CNS, of which a few were CD4+ and most were CD8+; CD20-positive lymphocytes (B-lymphocytes or plasma cells) were described as 'sparse' in the perivascular cuffs. Similarly, in fatal WNV infection in two elderly people (Kelley et al. 2003), inflammatory cells were mostly CD3+ T-lymphocytes and rarely CD20+. Flow cytometry of CSF cytological samples taken from 11 WNV-infected human transplant recipients showed that the atypical lymphocytes and plasma-cell-like cells seen by light microscopy were almost exclusively T-lymphocytes (Kleinschmidt-DeMasters et al. 2004).

West Nile virus immunoglobulin $\mathrm{M}$ (IgM) in human CSF (Alpert, Fergeson \& Noel 2003; Pupo-Antunez et al. 2008) and in human neonates (Alpert et al. 2003) is considered to be diagnostic of WNV infection, since IgM passes neither the blood brain barrier (BBB) nor the placenta. Studies in horses with naturally occurring WNV encephalitis (Ostlund et al. 2001; Porter 2004) showed low levels of CSF WNV IgM compared with high serum levels in the presence of an intact BBB. A human, Mexican patient with fatal WNV was shown to produce $\operatorname{IgM}$, IgG and IgA, in decreasing order of concentration, intrathecally within the CNS and not due to disruption of the BBB (Pupo-Antunez et al. 2008). Intrathecal Ig synthesis is originated by perivascular infiltrations of B-lymphocytes, which are locally matured and can be associated with CNS diseases (Porter 2004; Pupo-Antunez et al. 2008). In the current series of horses, CSF was not sampled for WNV IgM testing; however, had it been found to be IgM positive, its presence could have been explained by the presence of the few-to-several B-lymphocytes and plasma cells, as labelled by CD20 and MUM1 IHC in the CNS sections.

The significance of the lymphoplasmacytic orchitis of the stabled, non-sexually-active 2-year-old Thoroughbred colt (Case 3) is uncertain, since the WNV IHC and TEM failed to show evidence of virus and fresh tissue was not stored for RT-PCR. Lymphocytic orchitis associated with WNV has been reported in two immunosupressed renal transplant humans (Armah et al. 2007; Smith et al. 2004). The testicular sections of one (Smith et al. 2004) were IHC-negative for
WNV but ultrastructurally suggestive of flavivirus particles in Sertoli cell cytoplasmic vesicles by TEM, and IHC positive in seminiferous tubular epithelia in the other (Armah et al. 2007). The testicles of the older stallion (Case 4) in the present study were normal and undergoing spermatogenesis. Orchitis as a cause of testicular swelling is rare in horses, especially in young stallions and most-commonly traumatic or bacterial in origin. Viral orchitis due to influenza, arteritis and equine infectious anaemia viruses is recorded in some texts (Turner 2007); however, these diseases are currently absent in South Africa. Autoimmune orchitis (Turner 2007) due to viral breaching of the blood-testis barrier is a speculative possibility. One text mentions the potential for transmission in semen of Eastern and Western equine encephalitis viruses, WNV, vesicular stomatitis, AHS and equine infectious anaemia viruses (Timoney 2011). Equine viral arteritis virus is known to be transmitted in stallion semen (Timoney \& McCollum 2004).

Many of the horses in this series had gross oedema, including in the supraorbital fossae, and serosal haemorrhages mimicking lesions of horses dying of AHS (Mellor \& Hamblin 2004) and shunivirus (Van Eeden et al. 2012). Case 6, which had recovered from AHS, was still RT-PCR AHS positive, but viral culture negative from the spleen and lung, and showed the mildest pulmonary oedema. A recent study (Weyer et al. 2013) found that $16 \%$ of a group of 50 horses, vaccinated annually for AHS and living free in a high-risk AHS infection area, contracted subclinical or clinical AHSV field infection, with blood samples remaining RT-PCR positive for periods of up to or more than 130 days in survivors, but with tissue culture from positive blood being negative. Erythrocyte-bound virus coated with neutralising antibody was suggested, and the duration of positivity related to the longevity of circulating erythrocytes (Weyer et al. 2013).

The CNS of all cases in the present study was negative by various tests for other likely locally occurring viruses, ruling out co-infections. Borna disease virus (BDV), which causes neurological disease with prolific inflammatory response, has to date not been diagnosed in horses in South Africa, despite some surveillance for the BD virus (Dr G. H. Gerdes, personal communication, 2011). In the current WNV positive cases, although the inflammatory response was nonspecific and similar to that associated with BDV, the pathognomonic BDV-associated Joest-Degen inclusions were not seen in CNS sections (Caplazi \& Ehrensperger 1998; Katz et al. 1998). Successive viral infections, as in Case 6, or co-infections with arboviruses (Venter et al. 2009) are not surprising, since the mosquitoes transmitting WNV, other flaviviruses, bunyaviruses and alphaviruses and Culicoides species transmitting orbiviruses and some bunyaviruses, are similarly affected by temperature and rainfall and the diseases occur seasonally, simultaneously (Jupp 2001; Van Eeden et al. 2012; Venter et al. 2009).

The mechanism or mechanisms for the gross oedema and haemorrhage found in the WNV cases is unclear. In AHS, multifocal serofibrinous oedema and haemorrhages arise 
due to subcellular vascular injury (Erasmus 1972), with virus mainly targeting microvascular endothelial cells and monocyte-macrophages (Clift \& Penrith 2010). AHSV tissue tropism occurs in those tissues showing most consistent lesions (Clift \& Penrith 2010). In contrast, horses with neurological WNV infection have been found to be negative for WNV RNA in tissues other than CNS (Kleiboeker et al. 2004), as confirmed in the present study.

Pulmonary oedema can result from various nervous system disorders, including brain malignancies, trauma with increased intracranial pressure, infections and seizures. Suggested mechanisms include increased pulmonary capillary permeability, as well as rapid and massive centrally-mediated sympathetic catecholamine-induced discharge, resulting in elevated pulmonary vascular resistance (Caswell \& Williams 2007; Reuter-Rice, Duthie \& Hamrick2011). Barbiturate euthanasia leads to alveolar filling with proteinaceous fluid and foam filling the trachea. Foam flowing from the nose has been previously recorded as an incidental finding in horses and sheep dying of various causes (Caswell \& Williams 2007).

The gross necropsy findings imply that without a prior history of clinical signs, or in cases of acute death in South Africa and likely elsewhere in sub-Saharan Africa, gross lesions in horses with WNV (Venter et al. 2009) might be confused with other generally non-neurotropic but endotheliotropic viral infections such as AHS, EEV or EHV, or neurotropic viral infections like shunivirus (Van Eeden et al. 2012). Suitable sampling of the CNS to eliminate these viruses may be overlooked, and biosafety and personal protective measures omitted, thus exposing prosectors to the danger of zoonotic infection. WNV was unexpectedly transmitted to a veterinary student during necropsy on a positive horse whilst handling brain without facial protection (Venter et al. 2010).

\section{Conclusion}

The present study confirms the neuropathogenicity of South African field lineage 2 WNV strains in horses. Pathology is similar to that reported with Northern Hemisphere lineage $1 \mathrm{WNV}$ strains and more severe than that of the South African lineage 1 equine case reported to date, despite all cases showing severe, fatal neurological signs. Based on experimental findings in mice and hamsters, CNS lesions, sites and distribution suggest, but do not prove, the various neural and/or vascular routes of WNV entry into the CNS, and this could explain some of the clinical signs seen. WNV IHC is found to be a poor method for detection of viral antigen in equine CNS compared with real-time RTPCR, confirming similar findings by other researchers. The real-time RT-PCR has the advantages of marked sensitivity and specificity and of being able to distinguish between the lineages. Severe inflammatory changes in several cases of South African lineage $2 \mathrm{WNV}$ equine infections are most likely ascribable to immunopathology. Specific IHC labelling identifies a predominance of T-lymphocytes and few-to- several B-lymphocytes and plasma cells perivascularly and scattered in the neural parenchyma in the CNS of lineage 1 and 2 cases, with monocyte-macrophages and some neutrophils more common intravascularly and variably perivascularly. The CNS presence of B-lymphocytes and plasma cells may explain intrathecal production of low levels of WNV IgM recorded previously in naturally infected horses showing neurological signs. Rabies, as well as locally occurring potentially zoonotic neurotropic flaviviruses, alphaviruses and bunya-family arboviruses, as well as AHS, EEV and EHV-1 and EHV-4 were excluded from CNS tissues in all cases by various tests.

\section{Acknowledgments}

The National Health Laboratory Services and National Research Foundation of South Africa are thanked for funding the WNV molecular biological tests. Thanks to the Section of Pathology, Department of Paraclinical Sciences, Faculty of Veterinary Science, UP, Onderstepoort for funding some of the necropsies, all of the HE sections and the IMH testing. Charmaine van Eeden and Juliet Mentoor are thanked for their help with the differential diagnostic RT-PCR laboratory testing of the tissue samples for shunivirus, flavivirus and alphavirus. Dr Melvyn Quan and Mr Christopher Joone of the Onderstepoort Department of Veterinary Tropical Diseases and Equine Research Centre are thanked for the molecular diagnostic AHS and EHV testing of specimens from most cases, Mrs Carina Lourens for viral isolations from Cases 3, 5 and 6 and Dr Truuske Gerdes for the culture of WNV from brain of Case 1 at the OVI. The staff of the histopathology laboratory of the Section of Pathology of the Faculty of Veterinary Science at Onderstepoort are thanked for the preparation of sections and Mrs Marie Smit, Rephima Phaswane and Naomi Timmerman for the manual immunohistochemical staining. Dr Josepha DeLay of the University of Guelph, Ontario, Canada, is sincerely thanked for the advice and avian and equine lineage 1 WNV positive tissue blocks used as immunohistochemistry controls. Drs Cynthia Donnellan, Patrick Page, Macarena Sanz, Arnold Mahne, Prof. Montague Saulez, Dr Ben Smit and Dr Frank Freeman are thanked for referring the WNV cases. Thank you to Prof. J. Lawrence and M. Williams for reviewing the manuscript. Mr Andre Robinson is gratefully acknowledged for his help with preparation of and corrections to the figure images. The histopathology laboratory of the Section of Pathology and the Zoonosis Research Unit of UP are acknowledged for storing in perpetuity the sections, wax-embedded tissues, RNA extract and frozen tissues from the cases of this report.

\section{Competing interests}

The authors declare that they have no financial or personal relationship(s) which may have inappropriately influenced them in writing this article.

\section{Authors' contributions}

J.H.W. (University of Pretoria) was project leader and performed the necropsies and histology plus majority of the 
write-up; S.V.N. (University of Pretoria) and S.H. (University of Pretoria) performed the molecular biochemical testing plus write-up for WNV and the alphaviruses; E.V.W. (University of Pretoria) did the EM and write-up on the testicle of Case 3 and M.V. (National Institute for Communicable Diseases) was overall supervisor, as well as scrutinisor and advisor on biochemical results and for the approval of the final manuscript.

\section{References}

Alpert, S.G., Fergeson, J. \& Noel, L.P., 2003, 'Intrauterine West Nile Virus: Ocular and systemic findings', American Journal of Ophthalmology 136, 733-735. http:// dx.doi.org/10.1016/S0002-9394(03)00452-5

Armah, H.B., Wang, G., Omalu, B.I., Tesh, R.B., Gyure, A., Chute, D. et al., 2007, 'Systemic distribution of West Nile virus infection: Post-mortem immunohistochemical study of six cases', Brain Pathology 17, 354-362. http://dx.doi.org/10.1111/ j.1750-3639.2007.00080.x

Autorino, G.L., Battisti, A., Deubel, V., Farrari, G., Forletta, R., Giovannini, A. et al. 2002, 'West Nile virus Epidemic in Horses, Tuscany Region, Italy', Emerging 2002, 'West Nile virus Epidemic in Horses, Tuscany Region, Italy', Emerging
Infectious Diseases 8, 1372-1378. http://dx.doi.org/10.3201/eid0812.020234

Bakonyi, T., Ivanics, E., Erdelyi, K., Ursu, K., Ferenczi, E., Weissenbock, H. et al., 2006, 'Lineage 1 and 2 strains of encephalitic West Nile virus, Central Europe', Emerging Infectious Diseases 12, 618-623. http://dx.doi.org/10.3201/eid1204.051379

Beasley, D.W.C., 2005, 'Recent advances in the molecular biology of West Nile virus', Current Molecular Medicine 5, 835-650. http://dx.dol. org/10.2174/156652405774962272

Brown, A.N., Kent, K.A., Bennett, C.J. \& Bernard, K.A., 2007, 'Tissue tropism and neuroinvasion of West Nile virus do not differ for two mouse strains with different survival rates', Virology 368, 422-430. http://dx.doi.org/10.1016/j. virol.2007.06.033

Buckweitz, S., Kleiboeker, S.B., Marioni, K., Ramos-Vara, J.A., Rottinghaus, A., Schwabenton, B. et al., 2003a, 'Serological, reverse transcriptase-polymerase chain reaction, and immunohistochemical detection of West Nile virus in a clinically infected dog', Journal of Veterinary Diagnostic Investigation 15, 324-329. http:// dx.doi.org/10.1177/104063870301500404

Buckweitz, S., Kleiboeker, S.B., Marioni, K., Ramos-Vara, J.A., Rottinghaus, A., Schwabenton, B. et al., 2003b, 'Serological, reverse transcriptase-polymerase chain reaction, and immunohistochemical detection of West Nile virus in clinically affected dog', Journal of Veterinary Diagnostic Investigation 15, 324-329. http://dx.doi.org/10.1177/104063870301500404

Bunning, M., Wilson, T.M. \& Bowen, R.A., 2004, in J.A.W. Coetzer \& R.C. Tustin (eds.), Infectious diseases of livestock, 2nd edn., vol. 2, pp. 1004-1011, Oxford (eds.), Infectious diseases of
University Press, Cape Town.

Bunning, M.L., Bowen, R.A., Cropp, C.B., Sullivan, K.G., Davis, B.S., Komar, N. et al., 2002, 'Experimental infection of horses with West Nile virus', Emerging Infectious 2002, 'Experimental infection of horses with West Nile virus', Em
Diseases 8, 380-386. http://dx.doi.org/10.3201/eid0804.010239

Cantile, C., Del Piero, F., Di Guardo, G. \& Arispici, M., 2001, 'Pathologic and immunohistochemical findings in naturally occurring West Nile virus infection in horses', Veterinary Pathology 38, 414-421. http://dx.doi.org/10.1354/ vp.38-4-414

Cantile, C., Di Guardo, G., Eleni, C. \& Arispici, M., 2000, 'Clinical and neuropathological features of West Nile virus equine encephalomyelitis in Italy', Equine Veterinary Journal 32, 31-35. http://dx.doi.org/10.2746/042516400777612080

Caplazi, P. \& Ehrensperger, F., 1998, 'Spontaneous Borna disease in sheep and horses: Immunophenotyping of inflammatory cells and detection of MHC-I and MHC-II antigen expression in Borna encephalitis lesions', Veterinary Immunology and Immunopathology 61, 203-220. http://dx.doi.org/10.1016/S0165 2427(97)00128-1

Castillo-Olivares, J. \& Wood, J., 2004, 'Review article: West Nile virus infection of horses', Veterinary Research 35, 467-483. http://dx.doi.org/10.1051/ vetres:2004022

Caswell, J.L. \& Williams, K.J., 2007, 'Respiratory System', in Jubb, Kennedy and Palmer's Pathology of Domestic Animals, 5th edn., vol. 2, pp. 547-575, Elsevier Saunders, Sydney.

Chung, W.M., Buseman, C.M., Joyner, S.N., Hughes, S.M., Fomby, T.B., Luby, J.P. et al., 2013, 'The 2012 West Nile Encephalitis Epidemic in Dallas, Texas', Journal of the American Medical Association 310, 297-307. http://dx.doi.org/10.1001/ jama.2013.8267

Clift, S.J. \& Penrith, M.L., 2010, 'Tissue and cell tropism of African horse sickness virus demonstrated by immunoperoxidase labeling in natural and experimental infection in horses in South Africa', Veterinary Pathology 47, 690-697. http:// dx.doi.org/10.1177/0300985810370010

Danis, K., Baka, A., Pangiotopoulos, T., Economopoulou, A., Saraglou, G., Papa-Konidari, A. et al., 2010, 'ECDC Threat Assessment: Outbreak of West Nile virus infection in Greece, July-August 2010', European Centre for Disease Prevention and Control, 1-6.

Erasmus, B.J., 1972, 'Pathogenesis of African Horsesickness', 3rd International Conference on Equine Infectious Diseases, Paris, France, 17-20 July, pp. 1-11.

Frost, M.J., Zhang, J., Edmonds, J.H., Prow, N.A., Gu, X., Davis, R. et al., 2012, 'Characterization of virulent West Nile Kunjin strain, Australia, 2011', Emerging Infectious Diseases 18, 792-800. http://dx.doi.org/10.3201/eid1805.111720
Ghadially, F.N., 1988, Ultrastructural pathology of the cell and matrix, 3rd edn., Butterworths, London.

Guillon, J.C., Oudar, J., Joubert, L. \& Hannoun, C., 1968, 'Lesions histologiques du systeme nerveux dans l'infection à virus West Nile chez le cheval', Annales de I'Institut Pasteur 114, 539-550.

Haines, D.M. \& Chelack, B.J., 1991, 'Technical considerations for developing enzyme immunohistochemical staining procedures on formalin-fixed paraffinembedded tissues for diagnostic pathology', Journal of Veterinary Diagnostic Investigation 3, 101-112. http://dx.doi.org/10.1177/104063879100300128

Hayes, E.B., Sejvar, J.J., Zaki, S.R., Lanciotti, R.S., Bode, A.V. \& Campbell, G.L., 2005, 'Virology, pathology, and clinical manifestations of West Nile virus disease', Emerging Infectious Diseases 11, 1174-1179. http://dx.doi.org/10.3201/ eid1108.050289b

Hunsperger, E.A. \& Roehrig, J.T., 2006, 'Temporal analyses of the neuropathogenesis of a West Nile virus infection in mice', Journal of Neurovirology 12, 129-139. http://dx.doi.org/10.1080/13550280600758341

Jupp, P.G., 2001, 'The ecology of West Nile Virus in South Africa and the occurrence of outbreaks in humans', Annals of the New York Academy of Science 951, 143-152. http://dx.doi.org/10.1111/j.1749-6632.2001.tb02692.x

Katz, J.B., Alstad, D., Jenny, A.L., Carbone, K.M., Rubin, S.A. \& Waltrip II, R.W., 1998, 'Clinical, serologic, and histopathologic characterization of experimental Borna disease in ponies', Journal of Veterinary Diagnostic Investigation 10, 338-343. $\mathrm{http}: / / \mathrm{dx}$.doi.org/10.1177/104063879801000405

Kelley, T.W., Prayson, R.A., Ruiz, A.I., Isada, C.M. \& Gordon, S.M., 2003, 'The neuropathology of West Nile virus meningoencephalitis: A report of two cases and review of the literature', American Journal of Clinical Pathology 119, 749-753. $\mathrm{http}: / / \mathrm{dx}$.doi.org/10.1309/PU4R76JJMG1F81RP

Kimura, T., Sasaki, M., Okumura, M., Kim, E. \& Sawa, H., 2010, 'Flavivirus encephalitis: Pathological aspects of mouse and other animal models', Veterinary Pathology 47, 806-818. http://dx.doi.org/10.1177/0300985810372507

Kleiboeker, S.B., Loiacono, C.M., Rottinghaus, A., Pue, H.L. \& Johnson, G.C., 2004 'Diagnosis of West Nile virus infection in horses', Journal of Veterinary Diagnostic Investigation 16, 2-10. http://dx.doi.org/10.1177/104063870401600102

Kleinschmidt-DeMasters, B.K., Marder, B.A., Levi, M.E., Laird, S.P., McNutt, J.T. Escott, E.J. et al., 2004, 'Naturally acquired West Nile virus encephalomyelitis
in transplant recipients: Clinical, laboratory, diagnostic, and neuropathological features', Archives of Neurology 61, 1210-1220. http://dx.doi.org/10.1001/ features', Archives
archneur.61.8.1210

Kutasi, O., Bakonyi, T., Lecollinet, S., Bikisi, I., Ferenczi, E., Bahuon, C. et al., 2011, 'Equine encephalomyelitis outbreak caused by a genetic lineage 2 West Nile virus in Hungary', Journal of Veterinary Internal Medicine 25, 586-591. http://dx.doi. in Hungary', Journal of Veterinary Internd
$\mathrm{org} / 10.1111 / \mathrm{j} .1939-1676.2011 .0715 . x$

Kutasi, O., Biksi, I., Bakonyi, T., Ferenczi, E., Lecollinet, S., Bahuon, C. et al., 2009, 'Equine encephalomyelitis outbreak caused by a genetic lineage 2 West Nile virus in Hungary', American Association of Equine Practitioners Proceedings 65, 179.

Lim, S.M., Koraka, P., Osterhaus, A.D.M.E. \& Martina, B.E.E., 2011, 'West Nile virus: Immunity and pathogenesis', Viruses 3, 811-828. http://dx.doi.org/10.3390/ v3060811

Mellor, P.S. \& Hamblin, C., 2004, 'African horse sickness: Review article', Veterinary Research 35, 445-466. http://dx.doi.org/10.1051/vetres:2004021

Monath, T.P., Cropp, B.C. \& Harrison, A.K., 1983, 'Mode of entry of a neurotropic arbovirus into the central nervous system', Laboratory Investigation 48, 399-410.

Morrey, J.D., Olsen, A.L., Siddharthan, V., Motter, N.E., Wang, H., Taro, B.S. et al., 2008, 'Increased blood-brain barrier permeability is not a primary determinant for lethality of West Nile virus infection in rodents', Journal of General Virology 89, 467-473. http://dx.doi.org/10.1099/vir.0.83345-0

Morrey, J.D., Siddharthan, V., Wang, H., Hall, J.O., Skirpstunas, R.T., Olsen, A.L. et al., 2008, 'West Nile virus-induced acute flaccid paralysis is prevented by monoclonal antibody treatment when administered after infection of spinal cord neurons', Journal of Neurovirology 14, 152-163. http://dx.doi. org/10.1080/13550280801958930

Nir, Y., Beemer, A. \& Goldwasser, R.A., 1965, 'West Nile virus infection in mice following exposure to a viral aerosol', British Journal of Experimental Pathology 46, 443-449.

Ostlund, E., Crom, R.L., Pedersen, D.D., Johnson, D.J., Williams, W.O. \& Schmitt, B.J., 2001, 'Equine West Nile encephalitis, United States', Emerging Infectious Diseases 7, 665-669. http://dx.doi.org/10.3201/eid0704.017412

Papa, A., Danis, K., Baka, A., Bakas, A., Douglas, G., Lytras, T. et al., 2010, 'Ongoing outbreak of West Nile virus infections in humans in Greece, July-August 2010', Euro Surveillance 5, 19644.

Papa, A., Perperidou, P., Tzouli, A. \& Castilleti, C., 2010, 'West Nile Virus - neutralising antibodies in humans in Greece', Vector Borne and Zoonotic Diseases 10, 655-658. http://dx.doi.org/10.1089/vbz.2010.0042

Papa, A., Bakonyi, T., Xanthopoulou, K., Vasquez, A., Tenorio, A. \& Nowotny, N., 2011, 'Genetic characterisation of West Nile virus lineage 2, Greece, 2010', Emerging Infectious Diseases 17, 920-922. http://dx.doi.org/10.3201/eid1705.101759

Papa, A., Danis, K., Tsergouli, K., Tsioka, K. \& Gavana, E., 2011, 'Development time of IgG antibodies to West Nile virus', Archives of Virology 156, 1661-1663. http:// dx.doi.org/10.1007/s00705-011-1014-z

Papa, A., Xanthopoulou, K., Gewehr, S. \& Mourelatos, S., 2011, 'Research note: Detection of West Nile virus lineage 2 in mosquitoes during a human outbreak in Greece', Clinical Microbiology and Infection, 1-4.

Pennick, K.E., McKnight, C.A., Patterson, J.S., Latimer, K.S., Maes, R.K., Wise, A.G. et al., 2012, 'Diagnostic sensitivity and specificity of in situ hybridisation and immunohistochemistry for Eastern equine encephalitis virus and West Nile virus in formalin-fixed, paraffin-embedded brain tissues of horses', Journal of Veterinary formalin-fixed, paraffin-embedded brain tissues of horses', Journal of Veterinary
Diagnostic Investigation 24, 333-337. http://dx.doi.org/10.1177/1040638711435230 
Petersen, L.R. \& Roehrig, J.T., 2001, 'West Nile virus: a re-emerging globa pathogen', Emerging Infectious Diseases 7, 611-614. http://dx.doi.org/10.3201/ eid0704.017401

Platonov, A.E., Fedorova, M.V., Karan, L.S., Shopenskaya, T.A., Platonov, O.V. \& Zhuravlev, V.I., 2008, 'Epidemiology of West Nile infection in Volgograd, Russia, in relation to climate change and mosquito (Diptera: Culicidae) bionomics', Parasitology Research 103, S45-S53. http://dx.doi.org/10.1007/s00436-008-1050-0

Porter, M.B., 2004, 'Immunoglobulin M-capture enzyme-linked immunosorbent assay testing of cerebrospinal fluid and serum from horses exposed to West Nile virus by vaccination or natural infection', Journal of Veterinary Internal Medicine $18,866-870$.

Puls, R., 1994, Mineral levels in animal health: Diagnostic data, Sherpa International, Clearbrook, BC, Canada.

Pupo-Antunez, M., Dorta-Contreras, A.J., Vasquez, Y., Gonzalez-Hernandez, M., NorisGarcia, E., Padilla-Docal, B. et al., 2008, 'Detection of intrathecal IgM, IgG and IgA in a Cuban West Nile virus confirmed case', Arquiro de neuro-psiquiatria 66 (3A), 572-574.

Ramos-Vara, J.A., Miller, M.A. \& Valli, V.E.O., 2007, 'Immunohistochemical detection of multiple myeloma 1 /interferon regulatory factor 4 (MUM1/IRF-4) in canine plasmacytoma: Comparison with CD79a and CD20', Veterinary Pathology 44, 875-884. http://dx.doi.org/10.1354/vp.44-6-875

Reuter-Rice, K., Duthie, S. \& Hamrick, J., 2011, 'Neurogenic pulmonary edema associated with pediatric status epilepticus', Pediatric Emergency Care 27, 957-958. http://dx.doi.org/10.1097/PEC.0b013e3182309eac

Samuel, M.A., Wang, H., Siddharthan, V., Morrey, J.D. \& Diamond, M.S., 2007, 'Axonal transport mediates West Nile virus entry into the central nervous system and induces acute flaccid paralysis', Proceedings of the National Academy of Science USA 104, 17140-17145. http://dx.doi.org/10.1073/pnas.0705837104

Sanchez-Seco, M.P., Rosario, D., Quiroz, E., Guzman, G. \& Tenorio, A., 2001, 'A generic nested-RT-PCR followed by sequencing for detection and identification of members of the alphavirus genus', Journal of Virological Methods 95, 153-161. members of the alphavirus genus', Journal of Viro
$\mathrm{http}: / / \mathrm{dx}$.doi.org/10.1016/S0166-0934(01)00306-8

Scherret, J.H., Poidinger, M., Mackenzie, J.S., Broom, A.K., Deubel, V., Lipkin, W.I. et al., 2001, 'The relationships between West Nile and Kunjin viruses', Emerging Infectious Diseases 7, 697-705. http://dx.doi.org/10.3201/eid0704.017418

Schmidt, J.R. \& El Mansoury, H.K., 1963, 'Natural and experimental infection of Egyptian equines with West Nile virus', Annals of Tropical Medicine and Parasitology 57, 415-427.

Schuler, L.A., Khaitsa, M.L., Dyer, N.W. \& Stoltenow, C.L., 2004, 'Evaluation of an outbreak of West Nile virus infection in horses: 569 Cases (2002)', Journal of the American Veterinary Medical Association 225, 1084-1089. http://dx.doi. org/10.2460/javma.2004.225.1084

Sirbu, A., Ceianu, C.S., Panculescu-Gatej, R.I., Vasquez, A., Tenorio, A., Rebreanu, R. et al., 2011, 'Outbreak of West Nile virus infection in humans, Romania, July to October 2010', Euro Surveillance 16, 19762-19767.

Smith, R.D., Konoplev, S., Decourten-Myers, G. \& Brown, T., 2004, 'West Nile virus encephalitis with myositis and orchitis', Human Pathology 35, 254-258. http:// dx.doi.org/10.1016/j.humpath.2003.09.007

Snook, C.S., Hyman, S.S., Del Piero, F., Palmer, J.E., Ostlund, E.N., Barr, B.S. et al., 2001, 'West Nile virus encephalomyelitis in eight horses', Journal of the American Veterinary Medical Association 218, 1576-1579. http://dx.doi.org/10.2460/ javma.2001.218.1576

Steele, K., Linn, M.J., Schoepp, R.J., Komar, N., Geisbert, TW., Manduca, R.M. et al., 2000 ' Pathology of fatal West Nile virus infections in native and exotic birds durin the 1999 outbreak in New York City, New York', Veterinary Pathology 37, 208-224. http://dx.doi.org/10.1354/vp.37-3-208
Steinman, A., Banet, C., Sutton, G.A., Yadin, H., Hadar, H. \& Brill, A., 2002, 'Clinical signs of West Nile virus encephalomyelitis in horses during the outbreak in Israel in 2000', Veterinary Record 151, 47-49. http://dx.doi.org/10.1136/vr.151.2.47

Tber Abdelhaq, A., 1996, 'West Nile fever in horses in Morocco', Bulletin de l'Office International des Epizooties 11, 867-869.

Timoney, P.J., 2011, 'Diseases potentially transmitted with frozen or cooled semen', in A.O. McKinnon, E.L. Squires, W.E. Vaala \& D.D. Varner (eds.), Equine reproduction, 2nd edn., vol. 2, chapter 321, p. 3024, Wiley-Blackwell, Chichester, West Sussex, United Kingdom.

Timoney, P.J. \& McCollum, W.H., 2004, 'Equine viral arteritis', in Infectious diseases of livestock, 2nd edn., vol. 2, pp. 924-932, Oxford University Press Southern Africa, Cape Town

Turner, R.M.O., 2007, 'Testicular abnormalities', in J.C. Samper, J.F. Pycock \& A.O. McKinnon (eds.), Current therapy in equine reproduction, p. 198, Saunders, Elsevier, St Louis, Missouri. http://dx.doi.org/10.1016/B978-0-7216-02523.50034-5

Van den Berg Weermans, M.A. \& Dingemans, K.P., 1984, 'Rapid deparaffinization for electron microscopy', Utrastructural Pathology 7, 55-57. http://dx.doi. org/10.3109/01913128409141854

Van Eeden, C., Williams, J.H., Gerdes, G.H., Van Wilpe, E., Viljoen, A., Swanepoel, R. et al., 2012, 'Shuni virus as cause of neurologic disease in horses', Emerging Infectious Diseases 18, 318-321. http://dx.doi.org/10.3201/eid1802.111403

Venter, M., Human, S., Gerdes, G.H., Williams, J., Leman, P.A., Kemp, A. et al., 2008, 'Investigation of the pathogenesis of West Nile virus and other zoonotic flavi and alpha viruses in humans and horses in South Africa', in Proceedings of the South African Society for Veterinary Epidemiology and Preventive Medicine 8th Annual Conference, 20-22 August, Gauteng, South Africa.

Venter, M., Human, S., Van Niekerk, S., Williams, J., Van Eeden, C. \& Freeman, F., 2011 'Fatal neurologic disease and abortion in mare infected with lineage 1 West Nile virus, South Africa', Emerging Infectious Diseases 17, 1534-1536.

Venter, M., Human, S., Zaayman, D., Gerdes, G.H., Williams, J., Steyl, J. et al., 2009, 'Lineage 2 West Nile virus as cause of fatal neurologic disease in horses, South Africa', Emerging Infectious Diseases 15, 877-884. http://dx.doi.org/10.3201/ eid1506.081515

Venter, M., Steyl, J., Weyer, J., Zaayman, D., Blumberg, L., Leman, P.A. et al., 2010, 'Transmission of West Nile virus during horse autopsy', Emerging Infectious Diseases 16, 573-575. http://dx.doi.org/10.3201/eid1603.091042

Wang, H., Siddharthan, V., Hall, J.O. \& Morrey, J.D., 2009, 'West Nile virus preferentially transports along motor neuron axons after sciatic nerve injection of hamsters', Journal of Neurovirology 15, 293-299. http://dx.doi. org/10.1080/13550280902973978

Weyer, C.T., Quan, M., Joone, C., Lourens, C.W., MacLachlan, N.J. \& Guthrie, A.J., 2013 'African horse sickness in naturally infected, immunised horses', Equine Veterinary Journal 45, 117-119. http://dx.doi.org/10.1111/j.2042-3306.2012.00590.x

Williams, J., Mentoor, J., Van Wilpe, E. \& Venter, M., 2014, 'Comparative pathology of neurovirulent lineage 1 (NY99/385) and lineage 2 (SPU93/01) West Nile virus infections in BALBc mice', Veterinary Pathology, viewed 10 February 2014, from http://www.vet.sagepub.com/content/early/recent,http://dx.doi. 2014, from http://www.vet.sagep
org/10.1177/0300985813520246

Zaayman, D., Human, S. \& Venter, M., 2008, 'A highly sensitive method for the detection and genotyping of West Nile virus by real-time PCR', Journal of Virological Methods 157, 155-160. http://dx.doi.org/10.1016/j.jviromet.2008.12.014

Zaayman, D. \& Venter, M., 2012, 'West Nile virus neurological disease in humans, South Africa, September 2008-May 2009', Emerging Infectious Diseases 18, 2051-2054. http://dx.doi.org/10.3201/eid1812.111208 